\title{
Cytokine Expression Pattern in Benign Prostatic Hyperplasia Infiltrating T Cells and Impact of Lymphocytic Infiltration on Cytokine mRNA Profile in Prostatic Tissue
}

\author{
Georg E. Steiner, Ursula Stix, Alessandra Handisurya, Martin Willheim, \\ Andrea Haitel, Franz Reithmayr, Doris Paikl, Rupert C. Ecker, Kristian Hrachowitz, \\ Gero Kramer, Chung Lee, and Michael Marberger
}

Departments of Urology (GES, US, AH, FR, DP, RCE, KH, GK, MM), Pathophysiology (MW), and Clinical Pathology

(AH), University of Vienna Medical School, Vienna, Austria; and the Department of Urology (CL), Feinberg School

of Medicine, Northwestern University, Chicago, Illinois

\begin{abstract}
SUMMARY: The aim of the study is to characterize the type of immune response in benign prostatic hyperplasia (BPH) tissue. BPH tissue-derived T cells $(n=10)$ were isolated, activated (PMA + ionomycin), and analyzed for intracellular reactivity with anti-IFN- $\gamma$ and IL-2, $-4,-5,-6,-10$, and -13 , as well as TNF- $\alpha$ and $-\beta$ by four-color flow cytometry. Lymphokine release was tested using Th1/Th2 cytokine bead arrays. The amount of IFN- $\gamma$ and IL-2, $-4,-13$, and TGF- $\beta$ mRNA expressed in normal prostate $(n$ $=5$ ) was compared with that in BPH tissue separated into segments with normal histology $(n=5)$, BPH histology with $(n=10)$ and without $(n=10)$ lymphocytic infiltration, and BPH nodules $(n=10)$. Expression of lymphokine receptors was analyzed by immunohistology, flow cytometry, and RT-PCR. We found that $28 \pm 18 \%$ of BPH T helper cells were IFN- $\gamma^{+} / \mathrm{IL}-4^{-} \mathrm{Th} 1 \mathrm{cells}, 10$ $\pm 2 \%$ were IFN $-\gamma^{-} / \mathrm{IL}-4^{+}$Th2, and $12 \pm 6 \%$ were IFN- $\gamma^{+} / \mathrm{IL}-4^{+}$Th0 cells. In relation, cytotoxic and double-negative BPH T lymphocytes showed a slight decrease in Th1 and Th0 in favor of Th2. In double-positive BPH T lymphocytes, the trend toward Th2 (35 $\pm 15 \%)$ was significant (Th1: $12 \pm 7 \%$; Th0: $5 \pm 4 \%)$. Lymphokine release upon stimulation was found in the case of IL-2, IL-5, IFN- $\gamma$, and TNF- $\alpha>4 \mu \mathrm{g}$; of IL-4 $>2 \mu \mathrm{g}$; and of IL-10 $>1 \mu \mathrm{g} / \mathrm{ml}$. Expression of lymphokine mRNA in tissue was increased (2- to 10-fold) in infiltrated BPH specimens with and without BPH histology. The infiltrated BPH specimens with normal histology differed from those with BPH histology, most evident by the significant decrease in IFN- $\gamma$ and the increase in TGF- $\beta$ mRNA expression. Infiltrated BPH specimens with BPH histology expressed significantly more IFN- $\gamma$ (5-fold), IL-2 (10-fold), and IL-13 (2.8-fold) when compared with noninfiltrated BPH specimens. BPH nodules, however, showed the highest level of expression of IL-4 and IL-13, with only intermediate levels of IFN- $\gamma$ and very low levels of IL-2 mRNA. Immune response in histologically less transformed BPH specimens is primarily of type 1, whereas in chronically infiltrated nodular BPH and especially within BPH nodules, it is predominantly of type 0 or type 2. (Lab Invest 2003, 83:1131-1146).
\end{abstract}

\begin{abstract}
$B$ enign prostatic hyperplasia $(\mathrm{BPH})$ is a nodular

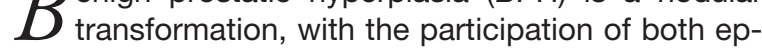
ithelial and fibromuscular stromal components (Franks, 1976). Presently BPH is considered a stromal disease (Bartsch et al, 1987). Further studies suggest a maturational sequence of stromal nodules, a possible significance of immunocompetent cells, and the notion that both stroma and epithelium respond with nodular hyperplasia to the stimulus, which causes BPH (Bierhoff et al, 1996, 1997).
\end{abstract}

\section{DOI: 10.1097/01.LAB.0000081388.40145.65}

Received September 30, 2002.

Sponsored in part by the Medizinisch-Wissenschaftlicher Fonds des Bürgermeisters der Bundeshauptstadt, Vienna, Austria (Grant No. 862), and by a research grant from Merck, Sharp \& Dohm, Whitehouse Station, New Jersey.

Address reprint requests to: Dr. Georg E. Steiner, Department of Urology, University of Vienna, Währinger Gürtel 18-20, 1090 Vienna, Austria. E-mail: georg.steiner@akh-wien.ac.at
An association of BPH with inflammatory processes was noted as early as 1937 (Moore, 1937). A study by Kohnen and Drach (1979) reported that 98\% of analyzed BPH specimens showed signs of an inflammatory process. We and others demonstrated that the largest portion of BPH tissue infiltrating leukocytes are T lymphocytes (Anim et al, 1998; Bierhoff et al, 1996; McClinton et al, 1990; Steiner et al, 1994; Theyer et al, 1992), in particular, activated CD4 ${ }^{+}$memory $\mathrm{T}$ lymphocytes (Steiner et al, 1994). Furthermore, it could be shown that BPH tissues and $T$ cell lines contain considerable amounts of IFN- $\gamma$, IL-2, and IL-4 mRNA, and proliferation experiments suggested that these lymphokines may alter the growth of prostatic stromal cells (Kramer et al, 2002). These results raise the question as to which kind of immune response is dominant.

Besides the phenotypic characteristics, the most important tool in defining a T cell immune response is the characterization of its cytokine expression pattern. 
Type-1 T lymphocytes are negative for IL-4 and IL-13, are sources of IFN- $\gamma$ or IL-2, and are involved in cell-mediated inflammatory reactions. They exhibit both cytotoxic and inflammatory functions (Del Prete et al, 1994; Mosmann and Coffman, 1989; Mosmann and Sad, 1996). Th1 clones induce delayed-type hypersensitivity reactions (Yamamura et al, 1991), and, at higher cell numbers, suppress B cell help (Del Prete et al, 1991). T lymphocytes belonging to the group of type- 2 cells are negative for IFN- $\gamma$ and IL-2, and positive for IL-4 or IL-13. They are commonly found in association with strong antibody and allergic responses (Mosmann and Coffman, 1989). A similar dichotomy has been reported for $\mathrm{CD}^{+} \mathrm{T}$ cells and for T cells expressing TCR- $\gamma / d$ (Ferrick et al, 1995; Romagnani, 1997; Sad et al, 1995).

This study, therefore, resorted to freshly isolated BPH T lymphocytes and intracellular lymphokine staining. Single CD4 or CD8 positive, double-positive, and double-negative subpopulations were analyzed for coexpression of IFN- $\gamma$ in combination with IL-2, -4, $-5,-6,-10$, or -13 , as well as TNF- $\alpha$ and $-\beta$. The effective amounts of lymphokines released by BPH T cells were analyzed by bead array assay.

The amounts of IFN- $\gamma$, IL-2, -4 , and -13 , and TGF- $\beta$ mRNA expressed in prostatic tissue were analyzed quantitatively by TaqMan Real-Time PCR using tissue-derived cDNA and correlation with $\beta$-actin. Cytokine mRNA expressed in normal prostate was determined by using cDNA prepared from prostate specimens derived from trauma victims 18 to 25 years of age. To analyze the effect of lymphocytic infiltration on lymphokine expression, we chose pieces of $\mathrm{BPH}$ resection tissue with a typical hyperplastic glandular component that were either strongly infiltrated or showed no increased lymphocytic infiltration. The lymphokine pattern within BPH nodules was analyzed using a group of cDNAs that was prepared from macroscopically identified central areas of BPH nodules. Finally, for reasons of comparison, a group of $\mathrm{BPH}$ resection chips was selected that was without hyperplastic glandular component but showed signs of lymphocytic infiltration. The pattern of cytokine receptor expression was analyzed by immunoperoxidase staining, RT-PCR, and triple immunofluorescence.

\section{Results}

\section{Intracellular Cytokine Profile of BPH T Lymphocytes}

Fresh primary BPH T cells $(n=10)$ were stained using anti-CD4, -CD8, and -IFN- $\gamma$ in combination with the above mentioned anticytokine antibodies. The percentages of anticytokine-reactive $\mathrm{T}$ cells of $\mathrm{CD}^{+} /$ $\mathrm{CD}^{-}$(Th), $\mathrm{CD}^{-} / \mathrm{CD}^{+}$(Tc), $\mathrm{CD}^{+} / \mathrm{CD}^{+}$(DP), and $\mathrm{CD}^{-} / \mathrm{CD}^{-}(\mathrm{DN}) \mathrm{T}$ cells and of cells coexpressing IFN- $\gamma$ were calculated by setting gates and calculation of positive cells (Fig. 1).

Analysis of BPH T lymphocytes in 10 patients revealed that $\mathrm{CD}^{+}$Th cells (mean: $55 \pm 21 \%$ ) were significantly more common than $\mathrm{CD}^{+} \mathrm{Tc}$ (mean: $28 \pm$ $15 \% ; p=0.012$ ), DP (mean: $8 \pm 7 \% ; p=0.000$ ), and DN (mean: $10 \pm 12 \% ; p=0.001) \mathrm{T}$ cells and that Tc cells were more frequent than DP and DN T cells. In addition a significant negative correlation between the percentage of Th and Tc cells $(p=0.01)$ and between Th and DN cells $(p=0.038)$ was observed (Table 1$)$.

Th1 cytokine-specific antibodies and anti-IFN- $\gamma$ and $-\mathrm{IL}-2$ reacted with $43 \pm 18 \%$ and $38 \pm 25 \%$ of $\mathrm{CD}^{+}{ }^{+}$Th cells, respectively. The percentages of IFN- $\gamma$ and IL-2 expressing cells of Th were significantly above those of $\mathrm{CD}^{+}$Tc and DN T cells (Fig. 2) $(p<$ $0.01)$. Th cells also showed a significantly increased anti-IFN- $\gamma(p=0.001)$ reactivity when compared with DP T cells (40\% versus $17 \%)$, while reactivity with anti-IL-2 was equally frequent $(42 \pm 31 \%$ of DP cells versus $38 \pm 25 \%$ of Th cells).
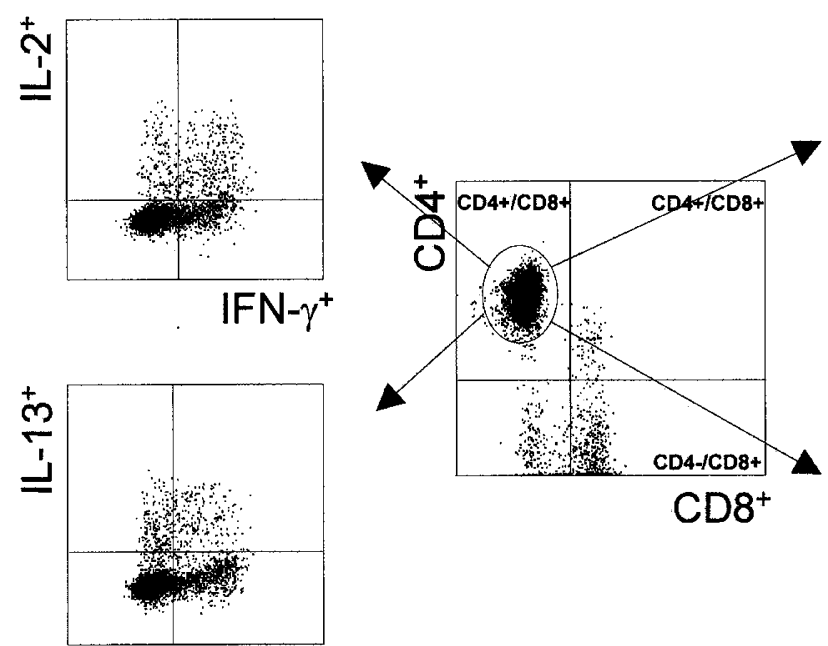

IFN- $\gamma^{+}$

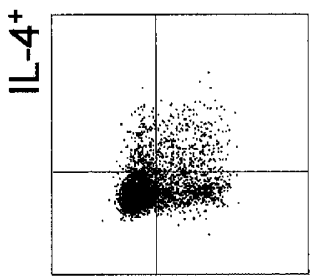

IFN- $\gamma^{+}$
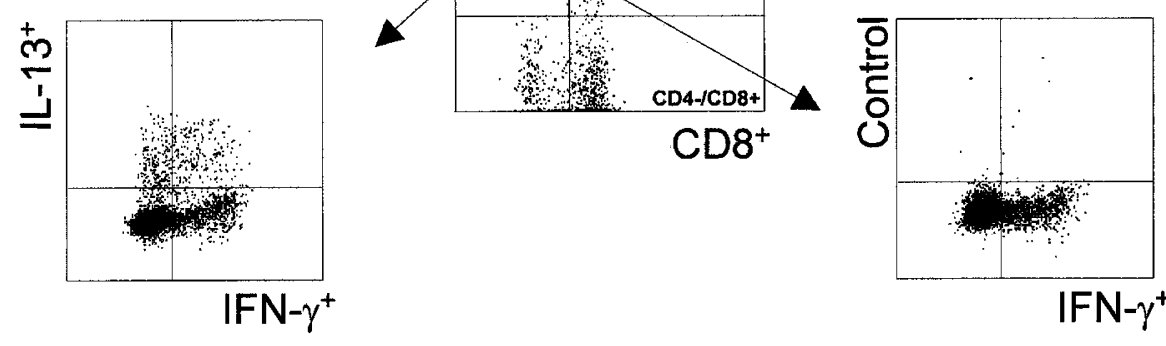

IFN- $\gamma^{+}$

Figure 1.

Benign prostatic hyperplasia T cells were stained using conjugated anti-CD4 APC and anti-CD8 PerCP in combination with anti-IFN- $\gamma$ FITC plus a second anti-PE-conjugated anticytokine antibody. T cells were divided into Th, Tc, DN, and DP T cell subsets, and the percentage of single or double anticytokine-reactive $T$ cells was calculated. 
Table 1. Distribution of Type-1, Type-2, and Type-0 Cytokine-Expressing T Cells in the Different BPH T Cell Subsets Analyzed for Intracellular Cytokine Staining and Four-Color Flow Cytometry

\begin{tabular}{|c|c|c|c|c|c|}
\hline \multirow{2}{*}{\multicolumn{2}{|c|}{$\begin{array}{l}\text { BPH T lymphocyte } \\
\text { subsets }\end{array}$}} & \multirow{3}{*}{$\frac{\% \text { Of BPH T Cells }}{55.3 \pm 20.6^{a}}$} & \multicolumn{3}{|c|}{ Intracellular lymphokine coexpression pattern of BPH T cells } \\
\hline & & & \multirow{2}{*}{$\begin{array}{c}\% \text { Of type } 1 \\
\text { IFN- } \gamma^{\text {pos }} \text { and IL-4 } \\
28.0 \pm 17.8 \%\end{array}$} & \multirow{2}{*}{$\begin{array}{c}\% \text { Of type } 2 \text { IL-4pos } \\
\text { and IFN- } \gamma^{\text {neg }}\end{array}$} & \multirow{2}{*}{$\begin{array}{c}\begin{array}{c}\% \text { Of type } 0 \mathrm{IL}-4^{\text {pos }} \\
\text { and IFN- } \gamma^{\text {pos }}\end{array} \\
12.3 \pm 5.6 \%\end{array}$} \\
\hline $\mathrm{CD}^{+} / \mathrm{CD}^{-}$ & Th cells & & & & \\
\hline $\mathrm{CD}^{-} / \mathrm{CD}^{+}$ & Tc cells & $27.8 \pm 15.3$ & $19.8 \pm 9.3 \%$ & $13.0 \pm 8.7 \%$ & $4.8 \pm 3.8 \%$ \\
\hline $\mathrm{CD}^{+} / \mathrm{CD}^{+}$ & DP T cells & $7.8 \pm 6.7$ & $12.0 \pm 7.3 \%$ & $34.5 \pm 15.4 \%$ & $5.0 \pm 3.5 \%$ \\
\hline $\mathrm{CD}^{-} / \mathrm{CD} 8^{-}$ & DN T cells & $10.0 \pm 11.5$ & $16.8 \pm 10.4 \%$ & $13.0 \pm 7.6 \%$ & $5.0 \pm 2.2 \%$ \\
\hline
\end{tabular}

$\mathrm{BPH}$, benign prostatic hyperplasia.

${ }^{a}$ Mean percentage $\pm \mathrm{SD}$.

More importantly DP T cells were significantly more frequently anti-IL-4 (42 $\pm 17 \%)$ and IL-13 (41 $\pm 15 \%)$ reactive than all other $\mathrm{BPH} \mathrm{T}$ cell subsets (mean range between $20 \%$ and $23 \% ; p<0.01$ ). Thus DP T cells differed significantly from $\mathrm{CD}^{+} \mathrm{Tc}$ cells and DN T cells by increased expression of IL-2, -4 , and -13 ( $p<$ 0.01 ). They differed from single CD4 ${ }^{+}$Th cells not only by significantly increased expression of IL-2 (in relation to IFN- $\gamma$ ) but also of IL-4 and IL-13. No significant differences between Tc and DP T cells were observed.

Coexpression analysis showed that Th cells consisted of significantly more IFN- $\gamma^{+} / \mathrm{IL}^{-} 4^{-}$type-1 (28\%) than IL-4 $4^{+} / \mathrm{IFN}-\gamma^{+}$type-0 (12.3\%, $\left.p=0.008\right)$ and $\mathrm{IL}-4^{+} / \mathrm{IFN}-\gamma^{-}$type-2 $(9.8 \%, p=0.024)$ cells, with no significant difference between the percentage of type- 0 and type- 2 cells.

In relation to the Th1:Th2 ratio in Th cells, $\mathrm{CD}^{+} \mathrm{Tc}$ showed a relative increase in Th2 cells (13\%) when compared with Th1 (20\%) and significantly less Th0 cells (5\%). A similar balanced ratio between Th1 and Th2 cells was observed in DN T cells.

In DP T cells, type- 2 cells were significantly more frequent when compared with all other $T$ cell subsets (mean percentage of type-2 cells of DP cells: $35 \%$ versus $13 \%$ of both Tc and DN, as well as $10 \%$ of Th; $p>0.001)$. Significant differences between the percentages of type- 1 and -0 cells were only seen within the $\mathrm{CD}^{+} \mathrm{Tc}$ population.

The mean anti-IL- 6 reactivity ranged between $0.9 \%$ in the case of Th and $4.8 \%$ of DP cells. Anti-IL-5 revealed a similar pattern of reactivity with $7.5 \pm 5.4 \%$ anti-IL-5 $5^{+}$DP cells followed by Tc and DN T cells (2.5\% and $2 \%$, respectively). Up to $4 \%$ of DP cells were anti-IL-10 ${ }^{+}$followed by Tc $\left(2.5 \pm 1.7 \% \mathrm{IL}-10^{+}\right.$ cells). Anti-TNF- $\alpha$ reactivity was very common and present in more than $59 \%$ of $\mathrm{T}$ cell subpopulations. Reactivity with anti-TNF- $\beta$, however, was restricted to only a small subset of less than a mean of $5.1 \%$ of BPH T cells (Table 2).

\section{Cytokine Release by BPH-T-Lymphocytes}

Release of cytokines by BPH T lymphocytes ( $n=6$ ) was analyzed using supernatants of BPH T cells that were kept either unstimulated or were stimulated with PMA or a combination of PMA and anti-CD3. Contamination by stromal and epithelial cells was avoided by culturing BPH T cells for three passages in suspension culture before use. The amount of lymphokines was analyzed using quantitative cytometric bead array assay.

In supernatants of unstimulated BPH T cell lines, four out of six (67\%) BPH T cell lines (Fig. 3 and Table 3) released IL-5 (range between 27 and $185 \mathrm{pg} / \mathrm{ml}$ ) and two out of six released IL-4 (33\%); Lines 2 and 6 showed 577 and $426 \mathrm{pg}$, respectively. Interestingly, both $\mathrm{IL}-4^{+}$lines were IL-5 ${ }^{-}$. The amount of IFN- $\gamma$ ranged between 15 and $596 \mathrm{pg} / \mathrm{ml}$ (66\% above 190 pg). IL-2 was almost negative, and TNF- $\alpha$ could be shown in supernatants of four of the six lines (range between 37 and 99 pg/ml). Two out of six BPH T cell lines released some IL-10 (> $60 \mathrm{pg} / \mathrm{ml})$.

In supernatants of PMA-stimulated BPH T cell lines, stimulation with PMA resulted in a multifold massive increase of cytokine release (Table 3). The release of IL-5, for example, was increased $>35$-fold and that of IFN- $\gamma$ as well as of TNF- $\alpha$ more than 29-fold. A heterogeneous pattern was observed in the case of IL-2, IL-4, and IL-10. An increase in the case of IL-2 was seen in only $33 \%$ of lines ( $>5$-fold). The mean increase in the case of IL-4 was more than 100-fold. However, $66 \%$ of lines showed almost no increase. Interestingly, the two lines that were $\mathrm{IL}-4^{+}$without stimulation (2 and 6) became IL-4 ${ }^{-}$upon PMA activation (down to 11 and $17 \mathrm{pg}$, respectively). The IL-10 response to PMA ranged between a 10 - and 400 -fold increase.

In supernatants of anti-CD3 and PMA-stimulated BPH T cell lines, the increase in lymphokine production was enormous, and it was necessary to dilute the supernatants 100-fold for appropriate results. The combination of anti-CD3 and PMA stimulated the release of all analyzed lymphokines. Comparison of PMA with PMA + anti-CD3-stimulated groups revealed in the case of IL-2 a $>450$-fold increase, of IFN- $\gamma>60$-fold, of TNF- $\alpha$ and IL-5 $>20$-fold, of IL-10 > 9-fold, and of IL-4 a > 6 -fold increase of all analyzed lines (Table 3). BPH T cell Line 1, for example, released 2 and 3 times more IFN- $\gamma$ and IL-2, respectively, when compared with BPH T cell Line 2 (Fig. 3). However, Line 1 also released twice as much IL-4, a typical Th2 cytokine. We also found a marked difference between the amount of IL-10 release (320 versus $5170 \mathrm{pg}$ of IL-10) by the BPH T cell lines. A typical example of this heterogeneity is given in Figure 3. 

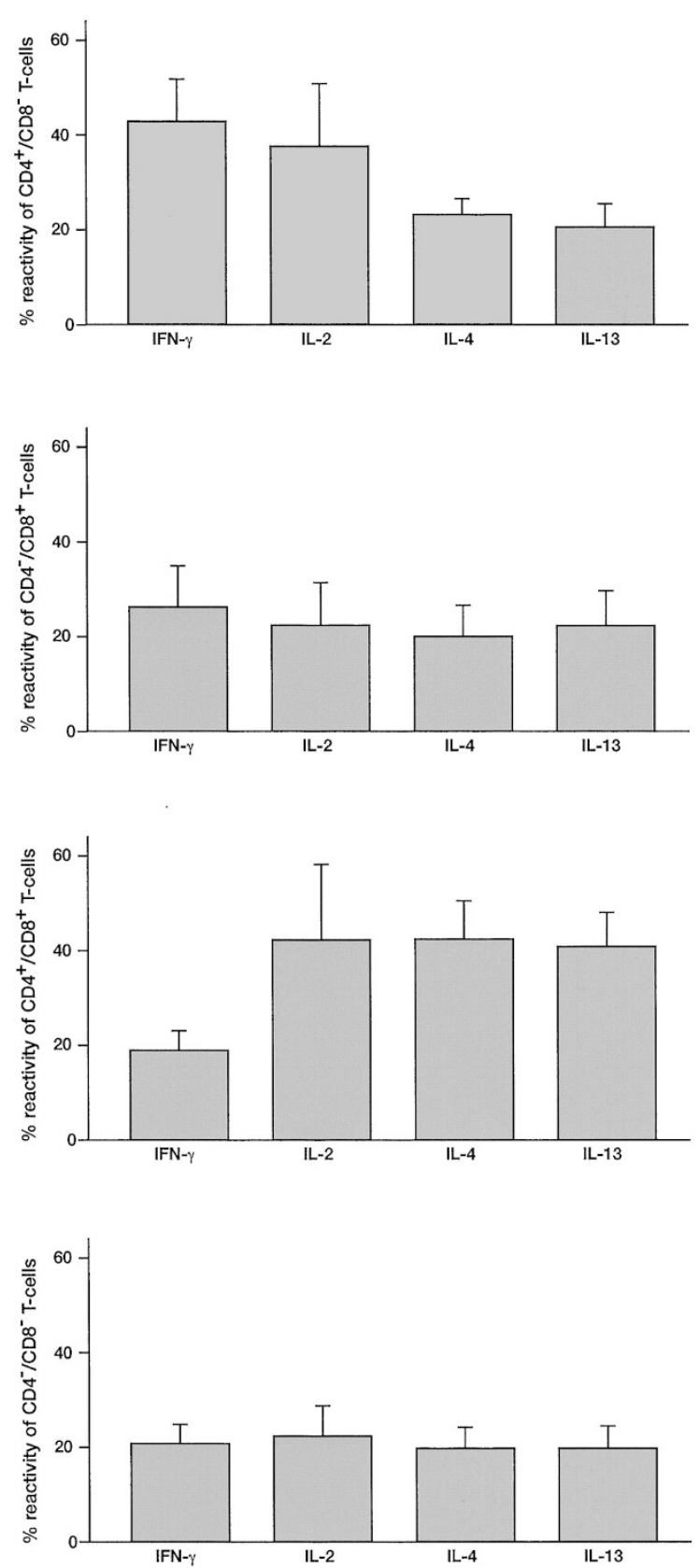

Figure 2.

Mean percentage and standard deviation of single anti-IFN- $\gamma$, IL-2, -4, and -13 reactive benign prostatic hyperplasia T cells $(n=10)$ of the four different subsets.

\section{Comparison of the Amount of Lymphokine mRNA Expressed in Normal and BPH Tissue Using TaqMan Real-Time PCR}

To determine cytokine mRNA expression quantitatively, TaqMan Real-Time PCR was performed using IFN- $\gamma$, IL-2, -4, and -13, and TGF- $\beta$-specific primers. The amount of cytokine mRNA was correlated with that of $\beta$-actin (Table 4). Normal prostatic cDNA was prepared from frozen specimens derived from trauma victims 18 to 25 years of age. BPH tissue-derived cDNA was prepared from transurethral resection
(TUR) chips that have been histologically analyzed and categorized.

IFN- $\gamma$. All normal prostate specimens expressed intermediate amounts of IFN- $\gamma$ mRNA (mean: 48), and all tested groups of cDNAs derived from BPH specimens expressed significantly increased amounts. Expression of IFN- $\gamma$ mRNA was most abundant in infiltrated BPH specimens (mean: 437) followed by BPH nodules (mean: 270) and BPH samples without hyperplastic glandular components that were infiltrated (mean: 152). Noninfiltrated BPH samples showed an increase in IFN- $\gamma$ mRNA expression that was $<2$-fold (mean: 86) when compared with normal prostate $(p=$ 0.023)(Table 5).

$I L-2$. In the normal prostate, noninfiltrated BPH specimens, and BPH nodules groups, expression of IL-2 mRNA was only marginal (mean: 18.4, 18.2, and 12.6, respectively). A 10-fold significantly increased expression of IL-2 mRNA ( $p=0.000)$ was observed in infiltrated BPH specimens with BPH histology (mean: 205) and in the group of BPH samples with normal histology that were infiltrated (mean: 191). However, in the case of infiltrated $\mathrm{BPH}$ specimens with $\mathrm{BPH}$ histology, this 10-fold increased IL-2 mRNA expression was associated with 3 times more IFN- $\gamma$ mRNA expression than in the group of infiltrated $\mathrm{BPH}$ tissue with normal histology.

$I L-4$. Compared with the very low levels of IL-4 mRNA expression observed in the group of normal prostate specimens (mean: 4.8), all other groups showed significantly increased expression of IL-4 mRNA. The increase was less pronounced in the cases of infiltrated BPH specimens with normal histology and of noninfiltrated BPH specimens (mean: 19.2 and 22, respectively), was intermediate in the group of infiltrated BPH specimens (mean: 55), and was strongest in the group of $\mathrm{BPH}$ nodules (mean: 116.9).

IL-13. In the groups of normal prostate specimens and of noninfiltrated BPH specimens uniform intermediate IL-13 mRNA expression was observed (mean: 29 and 36$)$. In the remaining experimental groups, expression of IL-13 mRNA was significantly increased. Similar to the expression pattern of IL-4 mRNA, the most abundant IL-13 mRNA expression was observed in the groups of BPH nodules (mean: 188.2) and infiltrated BPH specimens (mean: 90.1).

TGF- $\beta$. In normal prostate specimens, TGF- $\beta$ mRNA was massively expressed (mean: 178.2). Compared with these normal values, the only group that showed no significant increase in the expression of TGF- $\beta$ mRNA was the infiltrated BPH specimens with $\mathrm{BPH}$ histology group (mean: 365.8). Expression of TGF- $\beta$ mRNA was strongest in the group of infiltrated $\mathrm{BPH}$ specimens with normal histology (mean: 717.4$)$ followed by the group of BPH nodules (mean: 501.1) and the group of noninfiltrated BPH specimens (mean: 398.1).

Highly significant correlation between the amount of TGF- $\beta$ and IL-2 ( $p=0.007)$ mRNA was found in the normal prostate specimens group. No significant correlation between any of the cytokines was observed in 
Table 2. Profile of Additional Intercellular Lymphokine coexpression of the Four Different BPH T Cell Subsets

\begin{tabular}{|c|c|c|c|c|}
\hline \multirow[b]{2}{*}{ Cytokines } & \multicolumn{4}{|c|}{$\%$ Reactivity of BPH T Iymphocyte subpopulations } \\
\hline & $\begin{array}{l}\text { CD4 }{ }^{\text {pos }} \\
\text { CD8 }\end{array}$ & $\begin{array}{l}\text { CD4 }{ }^{\text {neg }} \\
\text { CD8 }\end{array}$ & $\begin{array}{l}\text { CD4 } 4^{\text {pos }} \\
\text { CD8 }\end{array}$ & $\begin{array}{l}\text { CD4 }{ }^{\text {neg }} \\
\text { CD8 }\end{array}$ \\
\hline$I L-6$ & $0.9 \pm 0.2 \%^{a}$ & $1.4 \pm 0.6 \%$ & $4.8 \pm 6.0 \%$ & $1.1 \pm 0.5 \%$ \\
\hline$I L-5$ & $1.1 \pm 0.5 \%$ & $2.5 \pm 1.1 \%$ & $7.5 \pm 5.4 \%$ & $2.5 \pm 0.5 \%$ \\
\hline$I L-10$ & $0.8 \pm 0.3 \%$ & $2.5 \pm 1.7 \%$ & $4.3 \pm 3.3 \%$ & $2.0 \pm 1.5 \%$ \\
\hline$T N F-\alpha$ & $69.8 \pm 24.3 \%$ & $60.0 \pm 28.6 \%$ & $64.0 \pm 27.0 \%$ & $62.3 \pm 21.1 \%$ \\
\hline$T N F-\beta$ & $2.3 \pm 1.1 \%$ & $2.1 \pm 1.0 \%$ & $5.1 \pm 4.6 \%$ & $1.4 \pm 0.6 \%$ \\
\hline
\end{tabular}

$\mathrm{BPH}$, benign prostatic hyperplasia.

${ }^{a}$ Mean percentage $\pm \mathrm{SD}$.

Negative control Unstimulated $\quad+$ PMA + anti-CD3

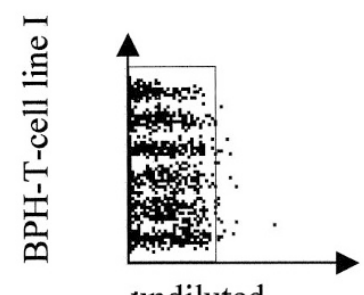

undiluted

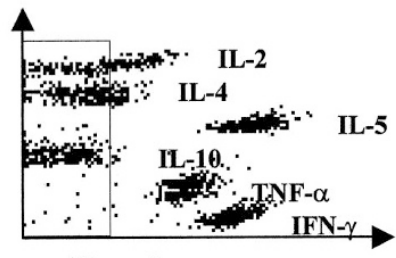

undiluted

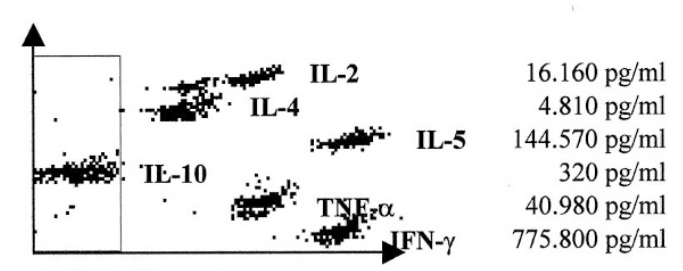

$1: 100$ diluted
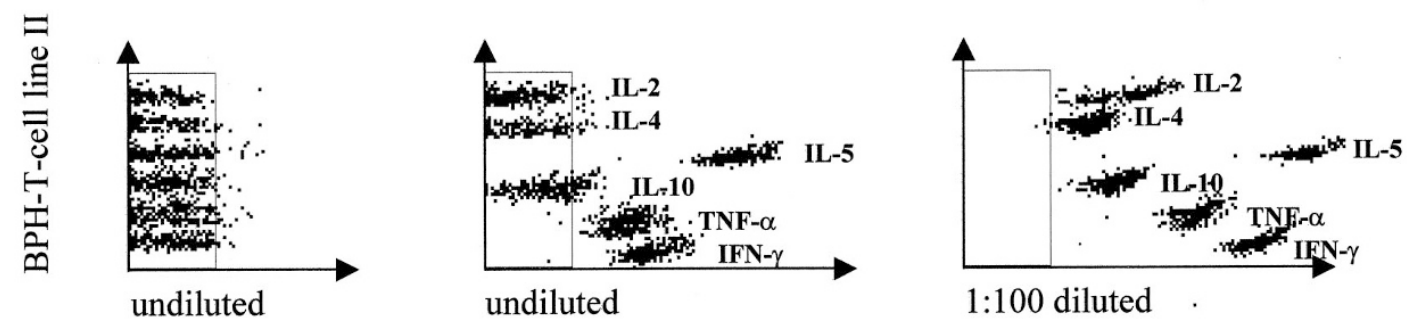

$5.560 \mathrm{pg} / \mathrm{ml}$

$1.900 \mathrm{pg} / \mathrm{ml}$ $204.760 \mathrm{pg} / \mathrm{ml}$

$5.170 \mathrm{pg} / \mathrm{ml}$

$34.940 \mathrm{pg} / \mathrm{ml}$ $405.720 \mathrm{pg} / \mathrm{ml}$

Figure 3.

Representative result of bead array analysis in culture supernatants of unstimulated and stimulated benign prostatic hyperplasia (BPH) $\mathrm{T}$ cells. Each of the six horizontal dot clouds represents the staining intensity for anticytokine-reactive beads for one cytokine. From top to bottom: IL-2, IL-4, IL-5, IL-10, TNF- $\alpha$, and IFN- $\gamma$. $X$-axis represents the staining intensity, corresponding to the amount of cytokine.

Table 3. Cytokine Release of primary BPH T Lymphocytes Analyzed by Bead Array

\begin{tabular}{lccc}
\hline & \multicolumn{3}{c}{ BPH T cells } \\
\cline { 2 - 4 } & $\begin{array}{c}\text { Unstimulated } \\
(\mathrm{pg} / \mathrm{ml})\end{array}$ & + PMA & + PMA + anti-CD3 \\
& $268 \pm 298$ & $10,520 \pm 4,519$ & $(\mathrm{pg} / \mathrm{ml})$ \\
\hline IFN- $\gamma$ & $4 \pm 6$ & $23 \pm 37$ & $594,780 \pm 185,171$ \\
IL-2 & $3 \pm 3$ & $454 \pm 766$ & $10,477 \pm 5,341$ \\
IL-4 & $196 \pm 151$ & $7,034 \pm 428$ & $3,077 \pm 1,533$ \\
IL-5 & $2 \pm 2$ & $303 \pm 435$ & $159,507 \pm 39,938$ \\
IL-10 & $53 \pm 49$ & $2,120 \pm 2,248$ & $2,950 \pm 2,451$ \\
TNF- $\alpha$ & & $43,343 \pm 9,801$ \\
\hline
\end{tabular}

$\mathrm{BPH}$, benign prostatic hyperplasia.

the group of infiltrated BPH specimens with normal histology. In the group of noninfiltrated BPH specimens, significant correlations were found between the amounts of IL-2 and IL-4 $(p=0.006)$ and between IFN- $\gamma$ and TGF- $\beta(p=0.019)$ mRNA expression. In the infiltrated BPH specimens group, the amount of IFN- $\gamma$ mRNA showed a highly significant correlation with the amount of IL-4 mRNA ( $p=0.001)$ and a negative correlation with the amount of TGF- $\beta(p=0.001)$ mRNA. In addition this group also showed significant 
Table 4. Effect of Lymphocytic Infiltration and Histologic Alteration on Cytokine mRNA Expression Pattern in Prostate Tissue

\begin{tabular}{|c|c|c|c|c|c|}
\hline \multirow[b]{3}{*}{ Infiltration ${ }^{a}$} & \multicolumn{2}{|c|}{ Normal prostate } & \multicolumn{2}{|c|}{ TUR/P-derived BPH specimens } & \multirow{3}{*}{$\begin{array}{c}\text { Suprapubic } \\
\text { prostatectomy-derived } \\
\text { BPH specimens } \\
\text { Central area of } \\
\text { BPH nodules } \\
\text { Not analyzed } \\
(\mathrm{n}=10)\end{array}$} \\
\hline & $\begin{array}{l}\text { Normal } \\
\text { histology }\end{array}$ & $\begin{array}{l}\text { Normal } \\
\text { histology }\end{array}$ & \multicolumn{2}{|c|}{ BPH histology } & \\
\hline & $\begin{array}{l}\text { Grade } 0 \\
(n=5)\end{array}$ & $\begin{array}{c}\text { Grades } 1 \text { and } 2 \\
(n=5)\end{array}$ & $\begin{array}{l}\text { Grade } 0 \\
(n=10)\end{array}$ & $\begin{array}{l}\text { Grades } 2 \text { and } 3 \\
\quad(n=10)\end{array}$ & \\
\hline IFN- $\gamma$ & $48.2 \pm 15.7^{b}$ & $152.4 \pm 46.2$ & $86.3 \pm 62.7$ & $437.4 \pm 188.6$ & $270.1 \pm 173.2$ \\
\hline IL-2 & $18.4 \pm 5.0$ & $191.6 \pm 40.5$ & $18.2 \pm 10.5$ & $205.3 \pm 95.3$ & $12.6 \pm 3.9$ \\
\hline IL-4 & $4.8 \pm 1.6$ & $19.2 \pm 5.1$ & $22.0 \pm 12.4$ & $55.0 \pm 39.1$ & $116.9 \pm 143.4$ \\
\hline IL-13 & $29.6 \pm 6.5$ & $45.8 \pm 9.3$ & $36.1 \pm 23.0$ & $90.1 \pm 44.3$ & $188.2 \pm 70.7$ \\
\hline TGF- $\beta$ & $178.2 \pm 57.7$ & $717.4 \pm 98.7$ & $398.1 \pm 141.5$ & $365.8 \pm 243.8$ & $501.1 \pm 317.9$ \\
\hline
\end{tabular}

$\mathrm{BPH}$, benign prostatic hyperplasia; TVR, transurethral resection.

${ }^{a}$ Grading of leucocytic infiltration: $0=$ No infiltration; $1=$ scattered infiltration (without clusters), $2=$ single foci of intense infiltration, $3=$ multifocal intense infiltration.

${ }^{b}$ Mean \pm SD 0.002

Table 5. $P$ Values of the Differences in Cytokine mRNA Expression

\begin{tabular}{llccccc}
\hline & & IFN- $\gamma$ & IL-2 & IL-4 & IL-13 & TGF- $\beta$ \\
\hline Normal prostate & vs BPH, normal histology & $\mathbf{0 . 0 0 9}$ & $\mathbf{0 . 0 0 9}$ & $\mathbf{0 . 0 0 9}$ & $\mathbf{0 . 0 2 1}$ & $\mathbf{0 . 0 0 9}$ \\
& vs BPH noninfiltrated & $\mathbf{0 . 0 2 3}$ & 0.759 & $\mathbf{0 . 0 0 7}$ & 0.901 & $\mathbf{0 . 0 0 3}$ \\
& Vs BPH infiltrated & $\mathbf{0 . 0 0 2}$ & $\mathbf{0 . 0 0 2}$ & $\mathbf{0 . 0 0 2}$ & $\mathbf{0 . 0 3 2}$ & 0.327 \\
& Vs BPH nodules & $\mathbf{0 . 0 0 2}$ & $\mathbf{0 . 0 4 8}$ & $\mathbf{0 . 0 0 2}$ & $\mathbf{0 . 0 0 2}$ & $\mathbf{0 . 0 0 6}$ \\
BPH & vs BPH noninfiltrated & $\mathbf{0 . 0 1 0}$ & $\mathbf{0 . 0 0 2}$ & 0.713 & 0.056 & $\mathbf{0 . 0 0 3}$ \\
Normal histology & vs BPH infiltrated & $\mathbf{0 . 0 0 3}$ & 0.806 & 0.326 & 0.066 & $\mathbf{0 . 0 1 4}$ \\
& Vs BPH nodules & $\mathbf{0 . 0 9 8}$ & $\mathbf{0 . 0 0 2}$ & 0.540 & $\mathbf{0 . 0 0 2}$ & 0.220 \\
BPH noninfiltrated & Vs. BPH infiltrated & $\mathbf{0 . 0 0 0}$ & $\mathbf{0 . 0 0 0}$ & 0.112 & $\mathbf{0 . 0 1 7}$ & 0.880 \\
& vs BPH nodules & $\mathbf{0 . 0 0 0}$ & 0.256 & 0.173 & $\mathbf{0 . 0 0 0}$ & 0.650 \\
BPH infiltrated & vs Central area of nodules & $\mathbf{0 . 0 0 9}$ & $\mathbf{0 . 0 0 0}$ & 0.762 & $\mathbf{0 . 0 0 5}$ & 0.545 \\
\hline
\end{tabular}

$\mathrm{BPH}$, benign prostatic hyperplasia.

${ }^{a}$ Mann-Whitney test, asymptotic significance; $p<0.05$ is significant.

negative correlations between TGF- $\beta$ and IL-2 $(p=$ $0.025)$ as well as IL-4 $(p=0.039)$, and a positive correlation between IL-2 and IL-4 $(p=0.036)$ mRNA. In the BPH nodules group, the amount of IFN- $\gamma$, IL-4, and IL-13 mRNA correlated significantly $(p=0.001)$.

\section{Cytokine Receptor Expression of Prostatic Epithelial and Stromal Cells}

cDNA of prostate carcinoma cell lines (DU145, LN$\mathrm{CaP}$, and $\mathrm{PC} 3$ ), $\mathrm{BPH}$ prostatic stromal cell (PSC) clones $(n=13)$, and six highly enriched BPH epithelial cell (EC) preparations were analyzed, and representative results are shown in (Fig. 4, A and B). $\mathrm{BPH}-\mathrm{EC}$ and carcinoma of the prostate (CaP) cells showed abundant expression of IFN- $\gamma$ (except LN$\mathrm{CaP}$ ), IL-4 (except BPH-EC 2), and IL-13R $\alpha$-chain mRNA. Expression of the three members of the $\mathrm{IL}-2 \mathrm{R}$ family in $\mathrm{CaP}$ cell lines was restricted to the IL-2R $\gamma$-chain (Fig. 4A), whereas in five out of six $\mathrm{BPH}-\mathrm{EC}$ preparations, transcripts of IL-2R $\alpha$ - and $\beta$-chain mRNA were found in addition.

PSC lines and clones showed significant expression of IFN- $\gamma$, IL-4, and IL-13 receptor $\alpha$-chain mRNA but were lacking IL-2R $\alpha$-chain mRNA transcripts. Expression of IL-2R $\gamma$ - and $\beta$-chain mRNA in PSCs was heterogeneous and therefore analyzed in more detail using additional polyclonal PSC lines $(n=9)$ and BPH-PSC clones (Fig. 4B). Two of the PSC lines are derived from normal prostate specimens and seven from BPH tissues. RT-PCR analysis revealed that all polyclonal normal PSC and BPH-PSC lines and 6 out of the $15 \mathrm{BPH}-\mathrm{PSC}$ clones expressed mRNA for IL-2R $\gamma$-chain. In the case of the IL-2R $\beta$-chain mRNA, the two normal PSC lines were negative, whereas 4 out of the 7 polyclonal BPH-PSC lines and 12 out of $15 \mathrm{BPH}$ PSC clones weakly expressed IL-2R $\beta$-chain mRNA (Fig. 4, A and B).

\section{Expression of Cytokine Receptors in BPH Tissue}

Acetone-fixed frozen sections of BPH tissue were stained using antigen affinity purified antisera directed against the three chains of the IL-2 receptor $(\alpha, \beta$, and $\gamma$ ) and the $\alpha$-chain of the IL-4 receptor and IL-13. Reactivity with anti-IL-2R $\alpha$-chain antisera was significant on infiltrating $T$ cells (Fig. 5A), but also a discrete 
a
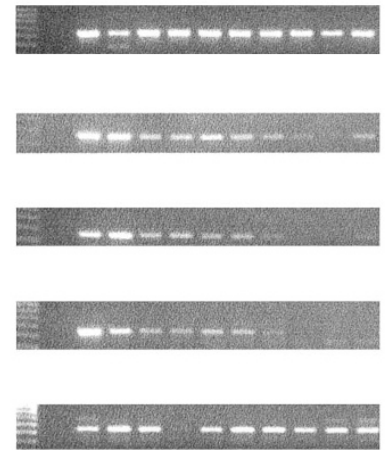

$-\rightarrow-3-\infty-\infty-2$
-IFN- $\gamma \mathbf{R} \alpha$-chain-

-IL-2R $\gamma$-chain-

-IL-2R $\beta$-chain-

-IL-2R $\alpha$-chain-

-IL-4R $\alpha$-chain-

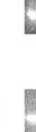

-IL-13R $\alpha$-chain-

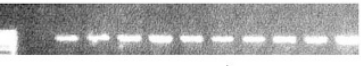

- $\beta$-Actin -

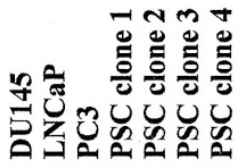
. 

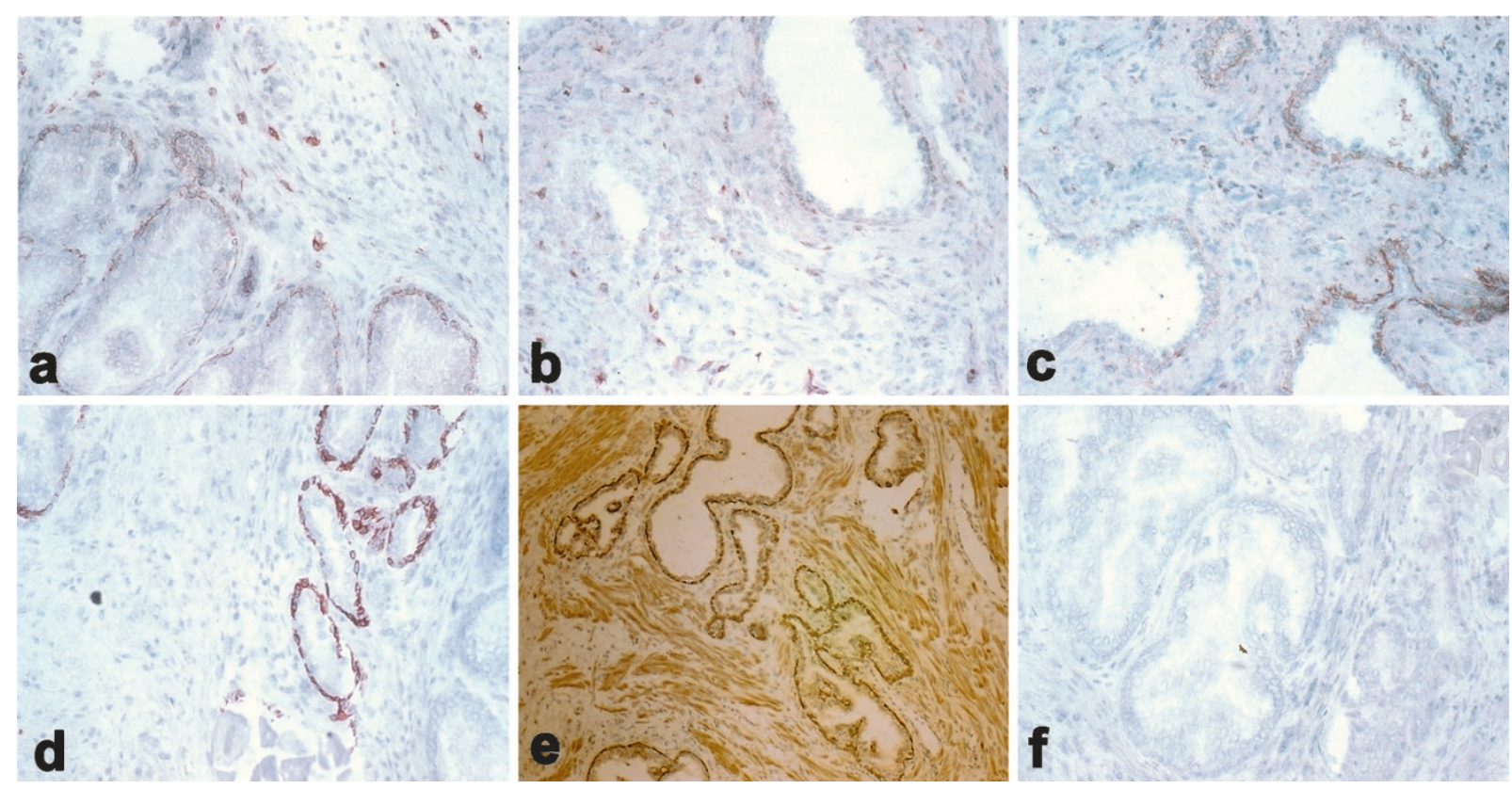

Figure 5.

Immunohistochemistry of frozen sections using IL-2R $\alpha$-chain (A), IL-2R $\beta$-chain (B), IL-2R $\gamma$-chain (C), and IL-4R $\alpha$-chain (E) specific antisera, as well as negative control sera (F). Reactivity with monoclonal anti-IL-13 is shown in $D$.

tibodies. Anti-IL-4 reactivity (red) was strongest on PECs and was more intense and not so restricted to the basal epithelial subset as it was the case for anti-IL-13 (Fig. 6F). Reactivity of stromal cells and infiltrating leukocytes was by far less intense when compared with epithelial cells with both anti-IL-4 and -13 . Anti-IL-2 reactivity could not be shown. Immunohistochemical staining for IFN- $\gamma$ (mAb and antiserum) revealed a strong membranous reactivity of all prostatic cell types. PEC and endothelial cells (data not shown) were slightly more positive, and focally increased reactivity was detected at sites of chronic inflammation, focal inflammatory atrophy, and glandular hyperplasia. Staining for IFN- $\gamma$ receptor $(\mathrm{R}) \alpha$-chain (antiserum) revealed a similar uniform reactivity, with a tendency toward a stronger reactivity of basal PEC. Anti-IFN- $\gamma \mathrm{R} \beta$-chain-specific antiserum also showed a uniform, yet only minor, reactivity of all prostatic cell types and seemed to accumulate on luminal secretory PECs (data not shown).

\section{Discussion}

This study examined for the first time the intracellular lymphokine expression pattern of $T$ cells derived from BPH specimens. To avoid a switching in the cytokine pattern or over-proportional outgrowth of subpopulations, BPH T cells were analyzed immediately after the isolation procedure. Among the CD4 ${ }^{+}$Th subset, $43 \pm$ $18 \%$ and $37 \pm 25 \%$ reacted with $\mathrm{mAb}$ directed against the type-1 cytokines IFN- $\gamma$ and IL-2, respectively. However, $14 \%$ of IFN- $\gamma^{+}$Th were also IL- $4^{+}$/ $\mathrm{IL}-13^{+}$. Therefore, the percentage of classic type- $1 \mathrm{Th}$ cells based on the anti-IFN- $\gamma$ reactivity was $29 \%$, and almost all of them coexpressed IL-2 (26\% IFN- $\gamma^{+}$/ IL $-2^{+}$Th cells). Within the Th subset, the second most common cytokine expression pattern was that of type- 0 cells characterized by the coexpression of type- 1 and -2 cytokines (mean IL- $4^{+} / \mathrm{IFN}-\gamma^{+}$and IL-13 ${ }^{+} /$IFN $-\gamma^{+}$cells: $14 \%$ ), while classic type-2 cells lacking type- 1 cytokines constitute only $10 \%$ of the Th cell population. This stood in sharp contrast to all other analyzed BPH T cell subpopulations, ie, single $\mathrm{CD}^{+}, \mathrm{DP}$, and DN T cells, which were found to express predominantly a type-2 cytokine pattern followed by significantly fewer type- 1 and type- 0 cells. This trend toward a predominance of a type-2 cytokine expression pattern was most pronounced in DP T cells in which $36 \%$ were of type 2 as compared with $9 \%$ of type 1 and $7 \%$ of type- 0 cells. Thus, DP T cells differed significantly from $\mathrm{CD}^{+}$Tc cells and DN T cells by increased expression of IL-2, -4 , and -13 $(p<$ 0.01 ). They differed from single $\mathrm{CD}^{+}$Th cells not only by significantly increased expression of IL-2 (in relation to IFN- $\gamma$ ) but also of IL-4 and IL-13.

Intracellular cytokine staining of freshly isolated $\mathrm{T}$ cells is the method of choice in characterizing $\mathrm{T}$ cell populations (Jung et al, 1993; Willheim et al, 1997, 1999). The cells are characterized according to their cytokine pattern. However, this method does not offer any insight into the amount of cytokines released. To detect locally released cytokines, which might exert an influence over adjacent cells, we deemed it necessary to perform further tests in addition to intracellular staining and PCR.

Considerable amounts of cytokines were detected in supernatants both without activation (due to 24-hour growth arrest using IL-2 withdrawal) or less than optimal activation using PMA alone. One-hundred percent of all supernatants from unstimulated $\mathrm{BPH}$ T cells contained IL-5 (> $51 \mathrm{ng}), 60 \%$ IFN- $\gamma$ (>194 ng), and TNF- $\alpha$ (> 57 

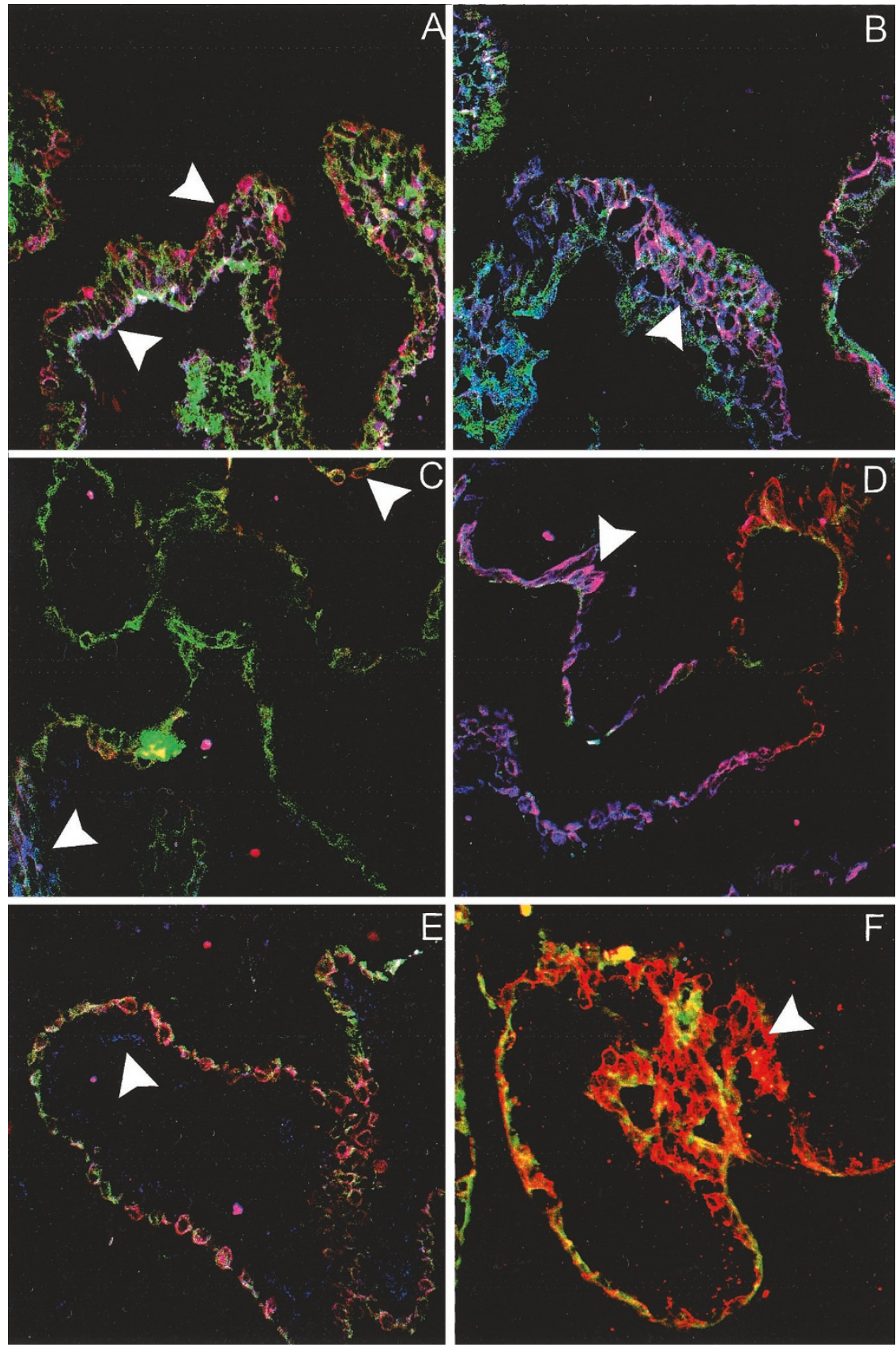

Figure 6.

Reactivity with anti-cytokeratin (ck)-18 (A, B, and E) and with anti-ck-13 (C, D, and F) is indicated in green. Reactivity with anti-IL-4R $\alpha$-chain is indicated in red Blue stainings represent reactivity with $\mathrm{IL}-13(\mathrm{~A}$ to $\mathrm{D})$ and $\mathrm{IL}-2 \mathrm{R} \gamma$-chain (E and $\mathrm{F}$ ).

ng), yet none contained relevant detectable amounts of IL-2, -4 , or -10 . Stimulation of BPH T cells with anti-CD3 and PMA (in place of antigen and antigen presenting cell) resulted in production of all analyzed cytokines by $100 \%$ of the examined cell lines. The largest variances were detected in the case of IL-10 (17-fold). Cell lines with the high amounts of single $\mathrm{CD} 4^{+} \mathrm{T}$ cells and the low amounts of DP and DN T cells, released at least twice as much IL-10 as all other analyzed cells lines. However, no direct correlation was found to exist between CD4 Th cells and IL-10, as cell lines showing almost identical percentages of CD4, CD8, DN, and DP showed up to 11 -fold differences in the amount of IL-10 released.
Although this method is not suited to determine the type of immune response, it became evident that only the secretion of IL-2 and IL-4 was anti-CD3 dependent and that four out of six cell lines did not respond to PMA stimulation. Furthermore, it struck our attention that the cell line that produced the largest amounts of IL-10 released the smallest amounts of IL-2 and IL-4. When comparing the total concentrations, it becomes apparent that the amount of released IFN- $\gamma$ (mean: 0.6 $\mu \mathrm{g} / \mathrm{ml}$ ) surpasses all, followed by IL-5 (mean: 0.16 $\mu \mathrm{g} / \mathrm{ml})$. At quite a distance, TNF- $\alpha$ (mean: $0.04 \mu \mathrm{g} / \mathrm{ml})$ follows in third place. IL-2, IL-4, and IL-10 constitute a distinct category and are released at relatively low 
levels. However, it has been taken into consideration that what is measured in the supernatant is a steady state of production and uptake/degradation. Thus it would be conceivable that, for example, the two T cell growth factors IL-2 and -4 are produced at similarly high levels and are massively used up.

The enormous variance in the levels of IL- 5 detected with the two different techniques (Bead array and flow cytometry) could be explained by the fact that the epitope recognized by anti-IL-5 antibody is structurally altered by the paraformaldehyde fixation. From our point of view, the speed of IL-5 release plays only a subordinate role.

Whether infiltration has an impact on the extent of cytokine expression in situ was analyzed by comparing the amount of cytokine mRNA expressed in $\mathrm{BPH}$ specimens with and without lymphocytic infiltration. The significantly increased expression of IFN- $\gamma$ (5fold), IL-2 (10-fold), and IL-13 (3-fold) mRNA in the group of infiltrated $\mathrm{BPH}$ specimens clearly indicates that lymphocytic infiltration of $\mathrm{BPH}$ is associated with increased cytokine mRNA expression. However, comparison of noninfiltrated BPH specimens with normal prostate specimens showed that these BPH specimens also revealed a higher expression of IFN- $\gamma$ (1.8-fold), TGF- $\beta$ (2.2-fold), and IL-4 (4.6-fold) mRNA. To analyze to which extent the benign hyperplastic growth process interferes with the cytokine mRNA expression pattern, a group of TUR/P-derived BPH chips exhibiting a normal histology were included in the study. All of the chips showed either a Grade-1 or -2 lymphocytic infiltration. Comparison of the cytokine mRNA expression pattern in this BPH group (normal histology) with noninfiltrated $\mathrm{BPH}$ specimens $(\mathrm{BPH}$ histology) revealed a significantly increased expression of IL-2 and IFN- $\gamma$ but not of IL-4 and -13 mRNA. These data suggest that in histologically normal parts of BPH specimens, a type-1 immune response prevails. The over-proportional increase of IFN- $\gamma$ (in relation to IL-2) together with a 2-fold increase of IL-4 and -13 mRNA expression in infiltrated $\mathrm{BPH}$ with $\mathrm{BPH}$ histology, when compared with BPH chips with normal histology, suggests a shift toward a type-0 immune response in hyperplastic transformed tissue. Theoretically, increased participation of Th0 cells is associated with advanced $\mathrm{BPH}$, and TUR/P chips with normal histology (prevailing type 1) are representatives of the initial phase of BPH development. Increased $\mathrm{IL}-4$ and IL-13 mRNA in the group of macroscopically identified central areas of BPH nodules associated with only very weak IL-2 but intermediate IFN- $\gamma$ mRNA expression might confirm this hypothesis. As a further indication for a predominant type-0 immune response in $\mathrm{BPH}$ nodules, the highly significant correlation among levels of IL-4 and -13 , and IFN- $\gamma$ mRNA expression might be used $(p>0.001)$.

It is remarkable that increased lymphokine mRNA expression in infiltrated $\mathrm{BPH}$ chips exhibiting normal histology was associated with a significant 4.2-fold increase of TGF- $\beta$ mRNA expression $(p=0.05)$ when compared with the group of normal specimens. No such significant increase was observed in infiltrated
BPH specimens with BPH histology. These specimens expressed significantly less TGF- $\beta$ mRNA than the group of BPH specimens with normal histology and noninfiltrated $\mathrm{BPH}$ specimens with $\mathrm{BPH}$ histology.

In the prostate TGF- $\beta$ has been shown to inhibit prostatic stromal cell growth by induction of differentiation (Lee et al, 1999) and to play a key role in the regulation of cell death by the induction of apoptosis of prostatic epithelial cells in the proximal region (Griffiths et al, 1993, 1996; Lee et al, 2001). In addition TGF- $\beta$ has evolved into a key molecular mediator stimulating extracellular matrix accumulation (Chung et al, 1996; Ignotz et al, 1987; Inagaki et al, 1994; Jimenez et al, 1994). TGF- $\beta$ functions as a major anti-inflammatory mediator in lung and skin fibrosis and has also been recognized as a major mediator of the immune response in the lung where it prevents persistent inflammation (McCormick et al, 1999). Recently, it has been shown that IFN- $\gamma$ inhibits the transcription of collagen in fibroblasts and abrogates its stimulation induced by TGF- $\beta$ (Chung et al, 1996; Ignotz et al, 1987; Inagaki et al, 1994; Jimenez et al, 1994). Thus, TGF- $\beta$ and IFN- $\gamma$ may exert opposite effects on collagen synthesis in the prostate. Because inflammatory $\mathrm{T}$ cells secrete both cytokines, their antagonistic interactions regulating collagen synthesis are likely to be of great importance in the maintenance of connective tissue homeostasis (Higashi et al, 1998; Kahari et al, 1990; Varga et al, 1990; Yuan et al, 1999; Yufit et al, 1995). IFN- $\gamma$ also abrogates other TGF- $\beta$ responses such as collagenase-3 expression in epithelial cells (Ala-Aho et al, 2000), as well as fibronectin and laminin receptor expression in monocytes (Bauvois et al, 1992). This antagonistic function might also account for the significant negative correlation obtained between the amount of IFN- $\gamma$ and TGF- $\beta$ ( $p=$ 0.001) mRNA expression in the group of infiltrated $\mathrm{BPH}$ tissues with BPH histology. Notably, this was the group with the most abundant IFN- $\gamma$ mRNA expression and the only group showing no significant increase in the expression of TGF- $\beta$ mRNA. In theory the combination of TGF- $\beta$ and IFN- $\gamma$ also inhibits differentiation of $\mathrm{T}$ cells and keeps $\mathrm{CD} 4^{+} \mathrm{T}$ cells in a proliferating Th0 state (Sad and Mosmann, 1994), with a memory phenotype similar to that described for $\mathrm{BPH}$ T cells (Steiner et al, 1994).

In BPH tissue, Th0 cells showed decreased IL-2 expression and were predominantly IL-4/IL-13 and IFN- $\gamma$ positive T cells. A non-Th1/Th2 representative cytokine pattern has been shown in autoimmune thyroiditis (Paschke et al, 1994), rheumatoid arthritis (Steiner et al, 1999; van der Graaff et al, 1999), and chronic hepatitis $B$ and $C$ virus infection (Bertoletti et al, 1997). IFN- $\gamma$ mRNA expression in nonlymphoid tissue has also been linked to intense lymphocyte infiltration in autoimmune thyroiditis (Paschke et al, 1994) and in colorectal carcinoma by Matsushita et al (1996).

Significant expression of IL-13 in normal prostate and increased expression of both IL-13 and IL-4 in $\mathrm{BPH}$, especially within $\mathrm{BPH}$ nodules, might upregulate the production of $3 \beta$-hydroxydehydroge- 
nase/isomerase type 1 (3 $\beta$-HSD) by PECs (Gingras and Simard, 1999). $3 \beta$-HSD is known to catalyze an essential step in the formation of active androgens and estrogens from dehydroepiandrosterone (Simard et al, 1996). Previously it has been shown that the major product of IL-4- and IL-13-treated normal PECs is 4-DIONE. It arises from a transient formation of testosterone (catalyzed by IL-4/IL-13-induced $3 \beta$ HSD) and dehydroepiandrosterone (catalyzed by $17 \beta-$ HSD). Expression of $17 \beta$-HSD type 5 in human prostate (El-Alfy et al, 1999; Lin et al, 1997) and enzyme activity has been shown previously (Dufort et al, 1999; Labrie et al, 1997). Thus up-regulation of $3 \beta-H S D$ activity by increased IL-4 and or IL-13 expression may lead to increased synthesis of testosterone and dehydrotestosterone, respectively (Labrie et al, 1985, 1994, 1997). In addition IL-4 and -13 have been shown to regulate gene expression of the tissue inhibitor of metalloproteinase-1 and -2 action in immortalized PECs (Wang et al, 1996). Expression of high affinity IL-13 receptors by the prostate carcinoma cell lines PC3, DU145, and LNCaP cells has already been demonstrated (Maini et al, 1997). It has also been established that IL-13 stimulates the proliferation of the prostate carcinoma cell lines (growth stimulation ranged between $21 \%$ and $39 \%$ of the three cell lines) (Maini et al, 1997). However, the expression pattern of both the IL-4 and IL-13 receptors in normal human prostate and in BPH tissue has not yet been investigated. Looking at our data, we concluded that PECs and PSCs express receptor chains involved in IL-4/ IL-13 binding (ie, $\alpha$-chains of the IL- 4 and IL-13 receptors and $\gamma$-chain of the IL-2 receptor) and that $\mathrm{IL}-13$ is the predominant cytokine that is bound to this receptor in normal and benign hyperplastic prostate.

IL-13 binding of epithelial cells has been shown for glomerular visceral epithelial cells (van den Berg et al, 2000), intestinal epithelial cells (Ceponis et al, 2000) and keratinocytes (Vita et al, 1995). The overexpression of IL-13 stimulates stromal cells to increase collagen, fibronectin, and tenascin synthesis or deposition as shown for the human skin (Oriente et al, 2000; Postlethwaite et al, 1992; Schmidt-Graeff et al, 1994), the lung (Doucet et al, 1998), and keloid fibroblasts (Oriente et al, 2000). Constitutive IL-13 expression in lungs of mice can cause inflammation and subepithelial fibrosis (Zhu et al, 1999), and administration of IL-13 inhibitor has been shown to block hepatic fibrosis during Th2-dominated inflammatory response (Chiaramonte et al, 1999). In Th1-dominated responses such as in rheumatoid arthritis, IL-13 functions as an inhibitor of the production of proinflammatory mediators. It has been shown that IL-13 transfected into fibroblasts of human synovial tissue explants blocks production of activated monocyte/ macrophage products IL- $1 \beta$, TNF- $\alpha$, and IL- 8 (Woods et al, 2000). A similar anti-inflammatory activity paired with a down-regulation of nitrite levels in aqueous humor and enhancement of TNF- and IL-6 synthesis in ocular tissue achieved by systemic administration of IL-13 was described in endotoxin-induced uveitis in a rat model (Marie et al, 1999). Unlike IL-4, IL-13 was shown to lack the ability to induce Th2 cell differentiation due to a lack of expression of functional IL-13 receptors by T cells (Zurawski and de Vries, 1994). Analysis of the role of both cytokines in inflammation suggested that both display common and disparate roles in regulating type-1 and type-2 immune responses. In type-2 responses they are generally proinflammatory and promote local chemokine production. In addition IL-4 promotes Th2 cell development in regional lymph nodes during type-2 responses, whereas IL-13 has a tempering effect. In type-1 responses, low levels of endogenous IL- 4 and -13 have a net anti-inflammatory effect by inhibiting local expression of TNF- $\alpha$, IFN- $\gamma$, and MCP chemokines (Ruth et al, 2000).

IL-10 might also play an important role in controlling epithelial and tumor cell growth and is expressed in prostate cancer tissue, but also by infiltrating $T$ lymphocytes in BPH. It has been demonstrated that transfection of IL-10 into prostate cancer cell lines blocks tumor cell growth, angiogenesis, and metastasis (Stearns et al, 1999a, 1999b).

TNF- $\alpha$ is released in substantial amounts by BPH T cells and has been shown to be capable of inducing cell cytotoxicity (Sintich et al, 1999) and prostate necrosis when injected locally (Kramer et al, 2001).

The consequences of increased or massive IL-5 expression have not yet been studied. In preliminary investigations using PCR, we were able to detect production of IL-5 in BPH tissue. It has not yet been shown which cells of the prostate express receptors for IL-5. In any case IL-5 is thought to be a type-2 cytokine.

In conclusion a considerable amount of data suggests that immune response in histologic BPH is of $\mathrm{TH} 0$ and $\mathrm{TH} 2$. We were also able to show that especially PECs massively bind the TH2 lymphokines IL-4 and IL-13 and express the respective receptors. In addition we showed that PECs produce IL-13 and, as already previously suggested, IL-4 (Kramer et al, 2002).

In light of the important roles played by these cytokines in hormone production, we consider these results highly interesting. To the best of our knowledge, classifying histologic alterations in $\mathrm{BPH}$ to a corresponding cytokine pattern has not yet been attempted.

We were astonished to find that in all BPH tissues, the production of TGF- $\beta$ was significantly elevated. The extent of the increase in TGF- $\beta$ production has to be seen in context with the release of its natural antagonist (IFN- $\gamma$ ). Only then does it become evident that prostatic cells, especially in infiltrated tissue, seem to counter-balance TGF- $\beta$ production. Although we did not include these data in this study, one should not fail to mention that BPH T cells also release considerable amounts of TGF- $\beta$ and FGF-2, thereby directly disrupting the balance.

It is highly unlikely that the increased production of TGF- $\beta$ is caused only by CD4 ${ }^{+}$suppressor T cells. While the isolated T cell population produces TGF- $\beta$ (by far less than stromal and epithelial cells), it also 
produces IFN- $\gamma, \mathrm{IL}-2$, and so forth, as was shown in this study on the cellular level (FACS). Suppressor cells are not capable of producing these growth factors. However, their phenotypic characteristics (CD4 ${ }^{+}$ and $\mathrm{CD}^{+} 5^{+}$) correspond with those described for suppressor $\mathrm{T}$ cells, and it cannot be excluded that a small percentage of suppressor $\mathrm{T}$ cells is among the infiltrating cells.

In our working hypothesis, we postulated the existence of a specific suppression mechanism, or a population of suppressor cells that actively suppresses the recognition of prostatic antigens. Sustained suppression is necessary because a whole array of secretory products of the prostate have antigenic properties. This becomes especially important with regard to the fact that production of these proteins reaches its full extent only in puberty, a period of time at which the immune system has already fully matured. It is highly likely that hormones play a crucial role in this. That is to say, age-dependent weakening of the immune system, coupled with modified hormonal secretion, leads to the deterioration of this barrier and to gradual infiltration of the prostate by lymphocytes. These infiltrating cells are responsible for the production of the indicated cytokines, which alter the micro-environment. Once initiated, this process leads to continual immigration of $T$ cells into the tissue. The cells seem to find favorable conditions, as they do not become apoptotic. Chronic activation leads to continual attraction of ever more $\mathrm{T}$ cells, attracted by increased production of proinflammatory cytokines such as IL-6, IL-8, IL-15, and IL-17 (Steiner et al, 2003), thus perpetuating chronic inflammation. When local accumulation of lymphocytes reaches a certain threshold, surrounding cells become targets and are killed either specifically or in bystander reactions, leaving behind vacant spaces, which are invaded by further leukocytes. These leukocyte clusters are detectable and are very often seen in close proximity to epithelium. A possible outcome of this could be the development of scar tissue. Formation of nodules and large amounts of connective tissue might be a consequence (Eickelberg, 2001).

\section{Materials and Methods}

\section{Specimen Collection}

$\mathrm{BPH}$ resection tissues from 30 patients were obtained by TUR immediately after surgery of noncatheterized patients. Trauma victims aged 18 to 25 years $(n=5)$ were used as normal controls. BPH tissue segments of the central region of $\mathrm{BPH}$ nodules $(n=8)$ were derived from suprapubic prostate specimens, and the central regions were identified macroscopically $(n=$ 8). TUR/P-BPH resection chips used for RNA preparation were analyzed histologically on an individual basis by the pathologist using frozen sections stained with hematoxylin and eosin. Segments of TUR/P-BPH resection chips with remaining normal histology were marked under the microscope and were used for mRNA preparation in the BPH tissue with normal histology group. In the BPH tissue with $\mathrm{BPH}$ histology group, only BPH resection chips with a typical nodular hyperplastic glandular component were selected. This group of BPH specimens with BPH histology was then further divided into a group showing typical signs of significant lymphocytic infiltration and cluster formation and a group without such signs of an inflammatory process.

\section{Pathologic Classification}

All specimens were separated into several parts for immunohistology or cell culture. The bulk of the material was embedded in paraffin, sectioned at $2 \mu \mathrm{m}$, and stained with hematoxylin and eosin. Histologic classification was performed according to Dohm (1991) and Franks (1976).

\section{Tissue Preparation}

$\mathrm{BPH}$ tissue was minced into $<3-\mathrm{mm}^{3}$ fragments and extensively washed with PBS containing heparin (Novo Nordisk A/S, Bagsvaerd, Denmark) to prevent potential peripheral blood contamination.

\section{Enzymatic Dissociation}

Fragments of prostatic tissue were incubated with 200 U/ml type-1 collagenase (Sigma Chemical Company, St. Louis, Missouri) and $100 \mu \mathrm{g} / \mathrm{ml}$ DNAse type-1 (Sigma) in RPMI 1640 medium plus 10\% FCS and 6\% penicillin/streptomycin solution (Gibco BRL Life Technologies, Gaithersburg, Maryland). The tissue was digested overnight at $37^{\circ} \mathrm{C}$. Digested tissue fragments were dissociated using a magnetic stirring bar, resulting in a heterogeneous cell suspension.

\section{Intracellular Cytokine Detection by Flow Cytometry}

Flow cytometric assessment of cytokine production was performed according to the technique described by Jung et al (1993) and modified by Willheim et al (1997, 1999). The primary BPH T cells were generated by the method described for primary BPH $\mathrm{T}$ cell enrichment (Steiner et al, 1994). Semi-pure BPH T cells were stimulated for 4 hours with phorbol 12myristate 13-acetate (10 ng/ml; Sigma) and ionomycin (1.25 $\mu \mathrm{M}$; Sigma) in the presence of monensin (1 $\mu \mathrm{M}$; Sigma) for 4 hours at $37^{\circ} \mathrm{C}$ in $5 \% \mathrm{CO}_{2}$. The cells were then harvested on ice, washed twice in PBS (PBS), and fixed with $2 \%$ formaldehyde $\left(1 \mathrm{ml}\right.$ per $2 \times 10^{6}$ cells; Merck) for 20 minutes. After two additional washes in PBS, the cells were re-suspended in Hank's balanced salt solution (supplemented with $0.3 \%$ BSA and $0.1 \%$ sodium-azide) and stored at $4^{\circ} \mathrm{C}$ in the dark until they were stained. The fixed cells were washed twice with PBS and made permeable with saponin (0.1\%; Sigma), re-suspended with $50 \mu$ l of saponin buffer-diluted antibodies, and incubated for 25 minutes at room temperature in the dark. The following monoclonal antibodies (MAbs) were used: cytokinespecific mouse anti-human MAb (fluoresceinisothiocyanate [FITC]-labeled anti-IFN- $\gamma$ [clone B27]) 
and rat antihuman MAb (phycoerythrin [PE]conjugated anti-IL-2 [MQ1-17H12], -IL-4PE [MP425D2], and -IL-13PE [JES10-5A2]). All MAbs were purchased from BD Pharmingen (San Diego, California). The anti-CD4 MAb and the anti-CD8 MAb were allophycocyanin and peridinin chlorophyll labeled, respectively (Becton Dickinson, Mountain View, California). Four-color staining was performed, and at least 5000 cells were analyzed on a FACSCalibur (Becton Dickinson) equipped with a two-laser system (488and $630-\mathrm{nm}$ wavelength, respectively). All cytokines were combined with anti-IFN- $\gamma$ and were stained in conjunction with CD4 and CD8. The data were analyzed with CELLQuest software (Becton Dickinson), and the results are expressed as the percentage of cytokine-producing cells. In terms of the generation of BPH-derived T lymphocyte cell lines, small cell clusters containing highly viable cells were separated from cellular debris by 5 minutes of simple segmentation in a $50-\mathrm{ml}$ tube. The remaining clumps were extensively washed and cultured in RPMI 1640 plus 10\% FCS (Gibco) in six-well plates (Falcon, Becton Dickinson) until the clumps became adherent (48 to 72 hours). Thereafter the culture medium was changed, and cells were further cultured in RPMI $1640+10 \%$ FCS and $100 \mathrm{U} / \mathrm{ml}$ of recombinant IL-2 (British Biotechnology Products, Ltd., Abingdon, United Kingdom) and 1\% phytohematoglutinin (Gibco). Media was changed twice a week, and outgrowing T cells were cultured in suspension cultures for three passages before testing.

\section{Lymphokine Secretion Assay}

After 24 hours T cell harvest cells were re-suspended in a medium containing no recombinant IL-2. On the day of harvest, cells were washed once and adjusted to a number of $1.5 \times 10^{6} \mathrm{BPH} \mathrm{T}$ cells $/ \mathrm{ml}$. BPH T cells were cultured either unstimulated (RPMI-1640+10\% FCS) or stimulated with PMA, or the combination of PMA + anti-CD3 (OKT 3, Ortho, $1 \mu \mathrm{g} / \mathrm{ml}$ ). After 24 hours supernatants were collected and frozen at $-70^{\circ} \mathrm{C}$.

\section{Cytometric Bead Array}

Fifty $\mu$ l of supernatant were incubated with $10 \mu \mathrm{l}$ of anti-IL-2, -4, -5, and -10, TNF- $\alpha$, and IFN- $\gamma$ conjugated cytokine capture beads (human Th1/Th2 cytokine CBA, Becton Dickinson, Mountain View, California) and with PE-conjugated detection antibodies for 3 hours at room temperature in the dark. The amount of cytokines was calibrated using recombinant standards. Following acquisition of sample data using FACSort (Becton Dickinson), the results were generated in graphical and tabular format using BD CBA analysis software.

\section{Total RNA Preparation}

RNA preparation of tissues was performed by a modified guanidium thiocyanate/phenol/chloroform extraction technique using TRIzoL Reagent (Gibco, Grand Island, New York). Reverse transcription was performed using $0.1 \mu \mathrm{g}$ total RNA (analyzed by 260 $\mathrm{nm}$ ) and GeneAmp RNA PCR kit (Perkin Elmer, Foster City, California). The mixture was incubated for 1 hour at $42^{\circ} \mathrm{C}$, and excess of enzyme was inactivated at $95^{\circ} \mathrm{C}$ for 5 minutes. All cDNAs were normalized to similarly integrated $\beta$-actin control signals. Amplified products were analyzed on 1.5\% agarose gel (Bio-Rad, Hercules, California) and stained with ethidium bromide.

\section{Reverse Transcriptase PCR}

Amplification of cytokine/receptor-coding cDNA was performed with DNA polymerase (AmpliTaq Gold, Perkin Elmer) using 30 cycles of PCR of similar amounts of CDNA, with specific primers. Resulting PCR fragments were separated by electrophoresis on $1.5 \%$ agarose gels (Bio-Rad Laboratories) in combination with a 100-bp size marker (Advanced Biotechnologies, Surrey, United Kingdom) and visualized and photographed after ethidium bromide staining under UV transillumination. cDNA of prostatic cells (normal prostatic SC, BPH-SC, BPH-EC, BPH-T, and CaP cells) and of positive control cells, ie, peripheral blood lymphocytes either unstimulated or stimulated with PHA M (Gibco BRL), was tested for lymphokine receptor mRNA expression using primer specific for the following: IFN- $\gamma \mathrm{R} \alpha$-chain (Yano et al, 1996); IL-2R $\gamma$-chain (Meazza et al, 1998); IL-2R $\beta$-chain (Meazza et al, 1998); IL-2R $\alpha$-chain (Clontech, Palo Alto California); IL-4R $\alpha$-chain (Clontech); IL-13R $\alpha$-chain (Ogata et al, 1998); and $\beta$-actin (Clontech).

\section{Real-Time PCR}

TaqMan Real-Time PCR was used to quantify IFN- $\gamma$, IL-2, IL-4, IL-13, and TGF- $\beta$ gene amplification using dual-labeled fluorogenic primers and probes specific for IFN- $\gamma$, IL-2, IL-4, IL-13, and TGF- $\beta$ and $\beta$-actin (PE Biosystems, Foster City, California). Reaction was performed in a Gene Amp 5700 Sequence Detection System (PE Biosystems). The amount of amplified lymphokine mRNA was correlated to $\beta$-actin mRNA content.

The impact of infiltration on lymphokine mRNA expression was analyzed by comparing infiltrated with noninfiltrated tissue samples. The amount of infiltration was graded 0 through 4 ( 0 for no infiltration, 1 for scattered infiltration without clusters, 2 for single foci of intense infiltration, and 3 for multi-focal intense infiltration). Tissue-derived cDNA was grouped as follows: normal prostate $(n=5)$, BPH tissue samples exhibiting normal histology but that were infiltrated (Grades 1 and 2, $n=5$ ), BPH tissue samples exhibiting $\mathrm{BPH}$ histology that were noninfiltrated (Grade $0, n$ $=10$ ), and $\mathrm{BPH}$ tissue samples exhibiting $\mathrm{BPH}$ histology that were infiltrated (Grades 2 and $3, n=10$ ). In addition the central area of macroscopically identified BPH nodules $(n=10)$ was separated and used for cDNA preparation. The differences between the amounts of cytokine mRNA expressed in the different experimental groups were compared statistically (Table 4). 


\section{Triple Staining Confocal Laser Scanning Microscopy}

IL-4R $\alpha$-chain was stained using rabbit anti-IL-4R $\alpha$-chain antiserum (Santa Cruz, St. Cruz, California) followed by species-specific biotinylated goat antirabbit (Biosource) and streptavidine conjugated red 670 (Gibco, Inchinnan, Scotland). Both PEC-specific mAbs were visualized using species-specific FITCconjugated goat anti-mouse antiserum (Biosource, Camarillo, California) and either cytokeratin (ck)-13-specific mAb (anti-cyt 8.12, clone K8.12, Sigma, St. Louis, Missouri) for basal or anti-ck18 mAb (Boehringer Mannheim, Mannheim, Germany) for secretory PEC. The free anti-mouse binding sites were blocked using 1:10 diluted mouse serum (Dako, Glastrup, Denmark) at room temperature followed by direct conjugated rat monoclonal anti-IL-13 PE (Pharmingen, Becton Dickinson, San Jose, California) antibody. Reactivity was analyzed simultaneously using confocal laser microscope with 3 photomultiplier (cLSM; Zeiss, Jena, Germany). Sensitivity of each of the three channels was adjusted using appropriate double reactive controls in which always one of the three antibodies was replaced by equal amounts of control sera or mouse $\lg \mathrm{G}_{1}$. Single anti-IL-4R $\alpha$-chain reactivity is indicated in red, anti-IL13 reactivity in blue, and anti-ck18 and -ck13 reactivity in green.

\section{References}

Ala-Aho R, Johansson N, Grenman R, Fusenig NE, LopezOtin C, and Kahari VM (2000). Inhibition of collagenase-3 (MMP-13) expression in transformed human keratinocytes by interferon-gamma is associated with activation of extracellular signal-regulated kinase-1, 2 and STAT1. Oncogene 19: 248-257.

Anim JT, Udo C, and John B (1998). Characterization of inflammatory cells in benign prostatic hyperplasia. Acta Histochem 100:439-449.

Bartsch G, Keen F, Daxenbichler G, Marth C, Margreiter R, Brungger A, Sutter T, and Rohr HP (1987). Correlation of biochemical (receptors, endogenous tissue hormones) and quantitative morphologic (stereologic) findings in normal and hyperplastic human prostates. J Urol 137:559-564.

Bauvois B, Roillard D, Sanceau J, and Wietzerbin J (1992). IFN-gamma and transforming growth factor-beta 1 differently regulate fibronectin and laminin receptors of human differentiating monocytic cells. J Immunol 148:3912-3919.

Bertoletti A, D'Elios MM, Boni C, De Carli M, Zignego AL, Durazzo M, Missale G, Penna A, Fiaccadori F, Del Prete F, and Ferrari C (1997). Different cytokine profiles of intrahepatic $T$ cells in chronic hepatitis $B$ and hepatitis $C$ virus. Gastroenterology 112:193-199.

Bierhoff E, Vogel J, Benz M, Giefer T, Wernert N, and Pfeifer $U$ (1996). Stromal nodules in benign prostatic hyperplasia. Eur Urol 29:345-354.

Bierhoff E, Walljasper U, Hofmann D, Vogel J, Wernert N, and Pfeifer U (1997). Morphological analogies of fetal prostate stroma and stromal nodules in BPH. Prostate 31:234-240.

Ceponis PJ, Botelho F, Richards CD, and McKay DM (2000). Interleukins 4 and 13 increase intestinal epithelial permeability by a phosphatidylinositol 3-kinase pathway. Lack of evidence for STAT 6 involvement. J Biol Chem 275:29132-29137.
Chiaramonte MG, Donaldson DD, Cheever AW, and Wynn TA (1999). An IL-13 inhibitor blocks the development of hepatic fibrosis during a T-helper type 2-dominated inflammatory response. J Clin Invest 104:777-785.

Chung KY, Agarwal A, Uitto J, and Mauviel A (1996). An AP-1 binding sequence is essential for regulation of the human alpha2(I) collagen (COL1A2) promoter activity by transforming growth factor-beta. J Biol Chem 271:3272-3278.

Del Prete GF, De Carli M, Ricci M, and Romagnani S (1991). Helper activity for immunoglobulin synthesis of $T$ helper type 1 (Th1) and Th2 human T cell clones: The help of Th1 clones is limited by their cytolytic capacity. J Exp Med 174:809813.

Del Prete GF, Maggi E, and Romagnani S (1994). Human Th1 and Th2 cells: Functional properties, mechanisms of regulation, and role in disease. Lab Invest 70:299-306.

Dohm G (1991). Hyperplasie und sogenannte atypische Hyperplasie der Prostata. In: Dörr W, Seifert G, editors. Pathologie der männlichen Genitale. Berlin, Heidelberg, New York. London: Springer-Verlag, 480.

Doucet C, Brouty-Boye D, Pottin-Clemenceau, Canonica GW, Jasmin C, and Azzarone B (1998). Interleukin (IL) 4 and IL-13 act on human lung fibroblasts. J Clin Invest 101:2129-2139.

Dufort F, Rheault P, Huang XF, Soucy P, and Luu-The V (1999). Characteristics of a highly labil human type 5 17[beta]-hydroxysteroid dehydrogenase. Endocrinology 140: 568-574.

Eickelberg O (2001). Endless healing: TGF-b, SMADs, and fibrosis. FEBS Lett 506:11-14.

El-Alfy M, Luu-The V, Huang XF, Berger L, Labrie F, and Pelletier G (1999). Location of type 517 [beta]-hydroxysteroid dehydrogenase, 3[beta]-hydroxysteroid dehydrogenase and androgen receptor in the human prostate by in situ hybridisation and immunocytochemistry. Endocrinology 140:1481-1491.

Ferrick DA, Schrenzel MD, Mulvania T, Hsieh B, Ferlin WG, and Lepper H (1995). Differential production of interferongamma and interleukin-4 in response to Th1- and Th2stimulating pathogens by gamma delta $T$ cells in vivo. Nature 19:255-257.

Franks LM (1976). Benign prostatic hyperplasia: Gross and microscopic anatomy. In: Grayhack JT, Wilson JD, Scherbenske MJ, editors: Benign Prostatic Hyperplasia 1976. Department of Health, Education and Welfare (NIH) Publication. Washington: US Government Printing Office, 76-1113.

Gingras S and Simard J (1999). Induction of 3[beta]hydroxysteroid dehydrogenase/isomerase type 1 expression by interleukin-4 in human normal prostate epithelial cells, immortalized keratocytes, colon, and cervix cancer cell lines. Endocinology 140:4573-4584.

Griffiths K (Chairman), Akaza H, Eaton CL, El Etreby M, Habib F, Lee C, Partin AW, Coffey DS, Sciarra F, Steiner GE, and Tenniswood MP (1993). Regulation of prostatic growth. In: Cockett ATK, Khoury S, Aso Y, Chatelain C, Denis L, Griffiths K, Murphy G, editors: 2nd International Consultation on Benign Prostatic Hyperplasia (BPH), 49-75.

Griffiths K (Chairman), Coffey DS, Cockett ATK, Sant Agnese A, Ichikawa T, Krieg M, Lee C, McKeehan W, Schalken J, Sciarra F, Steiner GE, Sigimura Y, and Yamanaka H (1996). Regulation of prostatic growth. In: Cockett ATK, Khoury S, Aso Y, Chatelain C, Denis L, Griffiths K, Murphy G, editors: 
3rd International Consultation on Benign Prostatic Hyperplasia (BPH), 73-115.

Higashi K, Kouba DJ, Song YL, Uitto J, and Mauviel A (1998). A proximal element within the human alpha 2(I) collagen (COL1A2) promoter, distinct from the tumor necrosis factoralpha response element, mediates transcriptional repression by interferon-gamma. Matrix Biol 16:447-456.

Ignotz RA, Endo T, and Massague J (1987). Regulation of fibronectin and type I collagen mRNA levels by transforming growth factor-beta. J Biol Chem 262:6443-6446.

Inagaki Y, Truter S, and Ramirez F (1994). Transforming growth factor-beta stimulates alpha 2(I) collagen gene expression through a cis-acting element that contains an Sp1binding site. J Biol Chem 269:14828-14834.

Jimenez SA, Varga J, Olsen A, Li L, Diaz A, Herhal J, and Koch J (1994). Functional analysis of human alpha 1(I) procollagen gene promoter. Differential activity in collagenproducing and -nonproducing cells and response to transforming growth factor beta 1. J Biol Chem 269:12684-12691.

Jung T, Schauer U, Heusser C, Neumann C, and Rieger C (1993). Detection of intracellular cytokines by flow cytometry. J Immunol Methods 159:197-207.

Kahari VM, Chen YQ, Su MW, Ramirez F, and Uitto J (1990). Tumor necrosis factor-alpha and interferon-gamma suppress the activation of human type I collagen gene expression by transforming growth factor-beta 1. Evidence for two distinct mechanisms of inhibition at the transcriptional and posttranscriptional levels. J Clin Invest 86:1489-1495.

Kohnen PW and Drach GW (1979). Patterns of inflammation in prostatic hyperplasia: A histologic and bacterialogic study. J Urol 121:755-760.

Kramer G, Steiner GE, Sokol P, Handisurya A, Klingler HC, Maier U, Foldy M, and Marberger M (2001). Local intratumoral tumor necrosis factor-alpha and systemic IFN-alpha $2 \mathrm{~b}$ in patients with locally advanced prostate cancer. J Interferon Cytokine Res 21:475-484.

Kramer G, Steiner GE, Handisurya A, Stix U, Haitel A, Knerer B, Gessl A, Lee Ch, and Marberger M (2002). Increased expression of lymphocyte-derived cytokines in benign hyperplastic prostate tissue, identification of the producing cell types and effect of differentially expressed cytokines on stromal cell proliferation. Prostate 52:43-58.

Labrie F, Dupont A, and Belanger A (1985). Complete androgene blockade for the treatment of prostate cancer. In: De Vita S, Hellman S, and Rosenberg SA editors. Important Advances in Oncology. Philadelphia: Lippincott, 193-217.

Labrie F, Simard J, Luu-The V, Pettelier G, Belghmi K, and Belanger A (1994). Structure, regulation and role of 3[beta]hydroxysteroid dehydrogenase, 17 [beta]-hydroxysteroid dehydrogenase and aromatic enzymes in the formation of sex steroids in classical and peripheral intracrine tisues. Bailleries Clin Endocrinol Metab 8:451-474.

Labrie F, Luu-The V, Lin SX, Labrie C, Simard J, Breton R, and Belanger A (1997). The key role of 17 [beta]hydroxysteroid dehydrogenase in sex steroid biology. Steroids $62: 148-158$.

Lee C, Sintich SM, Mathews EP, Shah AH, Kundu SD, Perry KT, Cho JS, Ilio KY, Cronauer MV, Janulis L, and Sensibar JA (1999). Transforming growth factor-[beta] in benign and malignant prostate. Prostate 39:285-290.
Lee C, Cockett A, Cussenot O, Griffiths K, Isaacs W, Schalken J, Buttyan R, Prins G, and Steiner GE (2001). Regulation of prostatic growth. In: Chatelian C, Denis L, Foo $\mathrm{KT}$, Khoury S, and McConnell J, editors. 5th International Consultation on Benign Prostatic Hyperplasia (BPH):81-111.

Lin HK, Jez JM, Schlegel BP, Peehl DM, Pachter JA, and Penning TM (1997). Expression and characterization of recombinant type 2 3[alpha]-hydroxysteroid dehydrogenase (HSD) from human prostate: Demonstration of bifunctional 3[alpha]/17[alpha]-HSD activity and cellular distribution. Mol Endocrinol 11:1971-1984.

Meazza R, Basso S, Gaggero A, Detotero D, Trentin L, Pereno R, Azzarone B, and Ferrini S (1998). Interleukin (IL)-15 induces survival and proliferation of the growth factordependent acute myeloid leukemia M-07e through the IL-2 receptor $\beta / \gamma$. Int J Cancer 78:189-195.

Maini A, Hillman G, Haas GP, Wang CY, Montecillo E, Hamzavi F, Pontes JE, Leland P, Pastan I, Debinski W, and Ruri RJ (1997). Interleukin-13 receptors on human prostate carcinoma cell lines represent a novel target for a chimeric protein composed of IL-13 and a mutated form of pseudomonas exotoxin. J Urol 158:948-953.

Marie O, Thillaye-Goldenberg B, Naud MC, and de Kozak Y (1999). Inhibition of endotoxin-induced uveitis and potentiation of local TNF- $\alpha$ and interleukin- 6 mRNA expression by interleukin-13. Invest Opthalmol Vis Sci 40:2275-2282.

Matsushita K, Takenouchi T, Kobayashi S, Hayashi H, Okuyama K, Ochiai T, Mikata A, and Isono K (1996). HLA-DR antigen expression in colorectal carcinomas: Influence of expression by IFN-gamma in situ and its association with tumour progression. Br J Cancer 73:644-648.

McClinton S, Eremin O, and Miller ID (1990). Inflammatory infiltrate in prostatic hyperplasia: Evidence of a host response to intraprostatic spermatozoa? Br J Urol 65:606-610.

McCormick LL, Zhang Y, Tootell E, and Gilliam AC (1999). Anti-TGF-beta treatment prevents skin and lung fibrosis in murine sclerodermatous graft-versus-host disease: A model for human scleroderma. J Immunol 163:5693-5699.

Moore RA. Inflammation of the prostate gland (1937). J Urol $38: 173$.

Mosmann TR and Coffman RL (1989). Heterogeneity of cytokine secretion patterns and functions of helper $\mathrm{T}$ cells. Adv Immunol 46:111-147.

Mosmann TR and Sad S (1996). The expanding universe of T-cell subsets: Th1, Th2 and more. Immunol Today 17:138141.

Ogata H, Ford D, Kouttab N, King TC, Vita N, Minty A, Stoeckler J, Morgan D, Girasole C, Morgan JW, and Maizel AL (1998). Regulation of interleukin-13 receptor constituents on mature human B lymphocytes. J Biol Chem 273:98649871.

Oriente A, Fedarko NS, Pacocha SE, Huang SK, Lichtenstein LM, and Essayan DM (2000). Interleukin-13 modulates collagen homeostasis in human skin and keloid fibroblasts. J Pharmacol Exp Ther 292:988-994.

Paschke R, Schuppert F, Taton M, and Velu T (1994). Intrathyroidal cytokine gene expression profiles in autoimmune thyroiditis. J Endocrinol 141:309-315.

Postlethwaite AE, Holness MA, Katai $H$, and Raghow $R$ (1992). Human fibroblasts synthesize elevated levels of ex- 
tracellular matrix proteins in response to interleukin 4 . J Clin Invest 90:1479-1485.

Romagnani S (1997). The Th1/Th2 paradigm. Immunol Today 18:263-266.

Ruth JH, Warmington KS, Shang X, Lincoln P, Evanoff H, Kunkel SL, and Chensue SW (2000). Interleukin 4 and 13 participation in mycobacterial (type-1) and schistosomal (type-2) antigen-elicited pulmonary granuloma formation: Multiparameter analysis of cellular recruitment, chemokine expression and cytokine networks. Cytokine 12:432-444.

Sad S and Mosmann TR (1994). Single IL-2-secreting precursor CD4 T cell can develop into either Th1 or Th2 cytokine secretion phenotype. J Immunol 153:3514-3522.

Sad S, Marcotte R, and Mosmann TR (1995). Cytokineinduced differentiation of precursor mouse CD8+ T cells into cytotoxic CD8 $+\mathrm{T}$ cells secreting Th1 or Th2 cytokines. Immunity 2:271-279.

Schmidt-Graeff A, Desmouliere A, and Gabbiani G (1994). Heterogeneity of myofibroblasts phenotypic features: An example of fibroblastic cell plasticity. Virchows Arch 425:3-24.

Simard J, Durocher F, Mebarki F, Turgeon C, Sanchez R, Labrie Y, Couet J, Trudel C, Rheaume E, Morel Y, Luu-The V, and Labrie $F$ (1996). Molecular biology and genetics of the 3 beta-hydroxysteroid dehydrogenase/delta5-delta4 isomerase gene family (Review). J Endocrinol 150(Suppl):189-207.

Sintich SM, Steinberg J, Kozlowski JM, Lee C, Pruden S, Sayeed S, and Sansibar JA (1999). Cytotoxic sensitivity to tumor necrosis factor-[alpha] in PC3 and LNCaP prostatic cancer cells is regulated by extracellular levels of SGP-2 (clusterin). Prostate 39:87-93.

Stearns ME, Rhim J, and Wang M (1999a). Interleukin 10 (IL-10) inhibition of primary human prostate cell-induced angiogenesis: IL-10 stimulation of tissue inhibitor of metalloproteinase-1 and inhibition of matrix metalloproteinase (MMP)-2/MMP-9 secretion. Clin Cancer Res 5:189-196.

Stearns ME, Garcia WU, Fudge K, Rhim J, and Wang Min (1999b). Role of interleukin 10 and transforming growth factor b1 in the angiogenesis and metastasis of human prostate primary tumor lines from orthopic implants in severe combined immunodeficiency mice. Clin Cancer Res 5:711-720.

Steiner G, Gessl A, Kramer G, Schöllhammer A, Förster O, and Marberger M (1994). Phenotype and function of peripheral and prostatic lymphocytes in patients with benign prostatic hyperplasia. J Urol 151:480-484.

Steiner G, Newman M, PaikI D, Stix U, Memaran-Dagdar N, Lee $C$, and Marberger M (2003). Expression and function of proinflammatory interleukin (IL)-17 and IL-17 receptor in normal, benign hyperplastic and malign prostate. Prostate. In press.

Steiner G, Tohidast-Akrad M, Witzmann G, Vesely M, Studnicka-Benke A, Gal A, Kunaver M, Zenz P, and Smolen JS (1999). Cytokine production by synovial $T$ cells in rheumatoid arthritis. Rheumatology 38:202-213.

Theyer G, Kramer G, Assmann I, Sherwood E, Preinfalk W, Marberger M, Zechner O, and Steiner G (1992). Phenotypic characterization of infiltrating leukocytes in BPH. Lab Invest 66:96-107.

van den Berg JG, Aten J, Anwar Chand M, Claessen N, Dijking L, Wijdenes J, Lakkis FG, and Weening JJ (2000). Interleukin-4 and interleukin-13 act on glomerular visceral epithelial cells. J Am Soc Nephrol 11:413-422. van der Graaff WL, Prins APA, Niers TMH, Dijkmans BAC, and van Lier RAW (1999). Quantitation of interferon gammaand interleukin-4-producing cells in synovial fluid and peripheral blood of arthritis patients. Rheumatology 38:214-220.

Varga J, Olsen A, Herhal J, Constantine G, Rosenblom J, and Jimenez SA (1990). Interferon-gamma reverses the stimulation of collagen but not fibronectin gene expression by transforming growth factor-beta in normal human fibroblasts. Eur J Clin Invest 20:487-493.

Vita N, Lefort S, Laurent P, Caput D, and Ferrara P (1995). Characterization and comparison of the interleukin 13 receptor with the interleukin 4 receptor on several cell types. J Biol Chem 24:3512-3517.

Wang M, Fudge K, Rhim JS, and Stearns ME (1996). Cytokine regulation of the matrix metalloproteinases and their inhibitors in human papillomavirus-transformed human prostatic tumor cell lines. Oncol Res 8:303-315.

Willheim M, Ebner C, Baier K, Kern W, Schrattbauer K, Thien R, Kraft D, Breiteneder H, Reinisch W, and Scheiner O (1997). Cell surface characterization of $\mathrm{T}$ lymphocytes and allergenspecific T cell clones: Correlation of CD26 expression with $\mathrm{T}(\mathrm{H1})$ subsets. J Allergy Clin Immunol 100:348-355.

Willheim M, Thien R, Schrattbauer K, Bajna E, Holub M, Gruber R, Baier K, Pietschmann P, Reinisch W, Scheiner O, and Peterlik M (1999). Regulatory effects of 1alpha, 25dihydroxyvitamin D3 on the cytokine production of human peripheral blood lymphocytes. J Clin Endocrinol Metab 84: 3739-3744.

Woods JM, Katschke KJ Jr, Tokuhira M, Kurata H, Arai KI, Campbell PL, and Koch AE (2000). Reduction of inflammatory cytokines and prostaglandin E2 by IL-13 gene therapy in rheumatoid arthritis synovium. J Immunol 165:2755-2763.

Yamamura M, Uyemura K, Deans RJ, Weinberg K, Rea TH, Bloom BR, and Modlin RL (1991). Defining protective responses to pathogens: Cytokine profiles in leprosy lesions [published erratum appears in Science. 1992;255:5040]. Science 11:277-279.

Yano N, Endoh M, Naka R, Takemura F, Nomoto Y, and Sakai $H$ (1996). Altered synthesis of interferon- $\gamma$ receptor by peripheral blood mononuclear cells from patients with $\lg A$ nephropathy and non-IgA proliferative glomerulonephritis. J Clin Immunol 16:71-79.

Yuan W, Yufit T, Li L, Mori Y, Chen SJ, and Varga J (1999). Negative modulation of alpha1(I) procollagen gene expression in human skin fibroblasts: Transcriptional inhibition by interferon-gamma. J Cell Physiol 179:97-108.

Yufit T, Vining V, Wang L, Brown RR, and Varga J (1995). Inhibition of type I collagen mRNA expression independent of tryptophan depletion in interferon-gamma-treated human dermal fibroblasts. J Invest Dermatol 105:388-393.

Zhu Z, Homer RJ, Wang Z, Chen Q, Geba GP, Wang J, Zhang $Y$, and Elias JA (1999). Pulmonary expression of interleukin-13 causes inflammation, mucus hypersecretion, subepithelial fibrosis, physiologic abnormalities, and eptaxin production. J Clin Invest 103:779-788.

Zurawski G and de Vries JE (1994). Interleukin 13, an interleukin 4-like cytokine that acts on monocytes and B cells, but not on T cells (Review). Immunol Today 15:19-26. 